\title{
Political Accountability in a System of Checks and Balances: The Case of Presidential Review of Rulemaking
}

\author{
Peter M. Shane*
}

We are living through a period of intense debateamong both academics and politicians-regarding the appropriate presidential role in supervising our vast national bureaucracy. That debate has two distinct, if overlapping, dimensions. One is constitutional: does the Constitution, read historically or otherwise, command a particular model of presidential supervision? ${ }^{1}$ The second addresses questions of policy: does government function best when the President enjoys plenary authority over the entire policy output of the bureaucracy? ${ }^{2}$ Or is government more effective when policy making influence is shared between the President and Congress, and among high-level bureaucratic administrators?

The Reagan and Bush Administrations took explicit positions on both sets of issues. On the doctrinal side, the Meese Justice Department expressly promulgated a systematic creed of constitutional interpretation. ${ }^{3}$ This Reagan-

* Dean and Professor of Law, University of Pittsburgh School of Law.

I would like to thank my fellow panelists for their helpful reactions to this paper, and Donna Miller, Iowa '95, for her research assistance. I am grateful also to the University of Iowa Law School Foundation, which supported part of this research in my waning days in Iowa City.

1. Professor Steven G. Calabresi, for example, argues that the Constitution dictates that the President have plenary control over all officials who help implement the laws. Steven G. Calabresi, Some Normative Arguments for the Unitary Executive, 48 Ark. L. Rev. 23 (1995). By way of contrast, Professors Larry Lessig and Cass Sunstein argue that, as an originalist matter, the Constitution authorized Congress "to limit the exercise of administrative powers as a condition to its grant of these powers to any officer of the government." Lawrence Lessig \& Cass R. Sunstein, The President and the Administration, 94 Colum. L. Rev. 1, 54 (1994).

2. Despite their view that the Constitution did not originally command strong Presidential control over all administration, Professors Lessig and Sunstein would answer this particular question in the affirmative-and reinterpret the Constitution in light of that conclusion. Lessig \& Sunstein, supra note 1, at 93-106.

3. See Office of Legal Policy, U.S. Dep't of Justice, Report to the Attorney General-Original Meaning Jurisprudence: A Sourcebook 
Bush (RB) legal dogma included what I have elsewhere called a "categorical" theory of the separation of powers. ${ }^{4}$ The theory asserted that, with a few explicit exceptions, the Constitution contemplates a stark compartmentalization of government powers as legislative, executive, or judicial; once a power is found to be executive, neither Congress, nor court may limit it. Under the RB view, not only was "executive" power deemed legally impregnable, but an extraordinary amount of policy making power was argued to be "executive." 5 The RB position held that, as a matter of constitutional dictate, the President enjoys plenary authority over all policy making involved in the execution of the laws. ${ }^{6}$

On the policy side, the Reagan and Bush Administrations' redesign of executive branch mechanisms for the centralized review of regulatory policy was wholly consistent with their separation of powers views. Initial steps taken by the first Reagan Administration could have been seen as relatively incremental innovations in what retrospectively appears to be a fairly modest management system that had evolved in linear fashion from the Nixon through the Carter Administrations. ${ }^{7}$ But the trend toward hierarchy and confidentiality intensified progressively in the late 1980s. It reached an apotheosis with the activities of the now-defunct President's Council on Competitiveness, headed during the Bush Administration by Vice-President Dan Quayle. ${ }^{8}$ The Council vigorously advocated a theory of the executive

(1987); Office of Legal Policy, U.S. Dep't of Justice, Guidelines on Constitutional Litigation (1988); Office of Legal Policy, U.S. Dep't of Justice, Report to the Attorney General-The Constitution in the Year 2000: Choices Ahead in Constitutional Interpretation (1988).

4. Peter M. Shane, Presidents, Pardons, and Prosecutors: Legal Accountability and the Separation of Powers, 11 YALE L. \& Pol'y Rev. 361, 371 (1993).

5. Id. at 361-62 n.4.

6. Id.

7. See Peter M. Shane, Presidential Regulatory Oversight and the Separation of Powers: The Constitutionality of Executive Order No. 12,291, 23 ARIz. L. Rev. 1235, 1235-1236 (1981); Robert V. Percival; Checks Without Balance: Executive Office Oversight of the Environmental Protection Agency, 54 LAw \& CONTEMP. Probs. Autumn 1991, at 127, 128-54 (1991); Caroline DeWitt, Comment, The President's Council on Competitiveness: Undermining the Administrative Procedure Act with Regulatory Review, 6 ADMIN. L.J. 759, 768-76 (1993).

8. See infra Part I. 
branch in which the President's policy roles, even in domestic affairs, are broadly discretionary, dischargeable in secret, relatively immune to congressional scrutiny (at least as to process), and subject to judicial review only in rare instances.

The Clinton Administration's stances are less clear. On one hand, the Clinton Administration has witnessed some of the traditionally bold lawyering for broad presidential authority that one expects from virtually any Administration. ${ }^{9}$ On the other hand, President Clinton's revamp of presidential regulatory oversight has, in some significant ways, stepped back from categorical separationism. Executive Order No. $12,866,{ }^{10}$ President Clinton's successor to the $\mathrm{RB}$ oversight system, pays significant deference to a theory of separation of powers more attentive to checks and balances - to the ideas, in particular, that Congress is first among co-equals in domestic policy making and that the Founders expected the three branches of our national government to hold one another to account. ${ }^{11}$ President Clinton has also embraced, in two conspicuous contexts, the wisdom of relative bureaucratic independence from presidential influence. He supported reauthorization of the independent counsel provisions of the Ethics in Government Act, ${ }^{12}$ and he has urged the reorganization of the Social Security Administration as an independent agency. ${ }^{13}$

9. For example, the Clinton Administration unsuccessfully followed the Bush Administration's lead in resisting the application of the Federal Records Act to electronic records in the Executive Office of the President. Armstrong v. Executive Office of the President, 1 F.3d 1274 (D.C. Cir. 1993). The Administration did succeed in opposing the application of the Federal Advisory Committee Act to the President's Task Force on National Health Care Reform, chaired by Hillary Rodham Clinton. Association of Am. Physicians and Surgeons v. Clinton, 997 F.2d 898 (D.C. Cir. 1993).

10. Exec. Order No. 12,866, 3 C.F.R. 638 (1993), reprinted in 5 U.S.C. $\S 601$ (Supp. 1993).

11. For an explication of "checked separationism" as a theory of constitutional design, see Shane, supra note 4, at 370-76.

12. Independent Counsel Reauthorization Act, Pub. L. No. 103-270, 108 Stat. 732 (1994); see Holly Idelson, Senators Set Aside Suspicions, Vote for Counsel Law Renewal, 51 Cong. Q. WKLy. Rep. 3205 (1993) (reporting that President Clinton and Attorney General Reno lobbied for independent counsel reauthorization).

13. Michael Wines, House Backs Independence for Social Security Agency, N. Y. Times, May 18, 1994, at A16, available in LEXIS, NEWS Library, CURNWS file. 
The RB categorical version of separation of powers is weakly rooted in the history of the Constitution on which it purports to be based, and, therefore, for rigorous constitutional originalists, it is not likely to be persuasive as a reading of constitutional command. ${ }^{14}$ Moreover, as I have argued elsewhere, it is a vision that seriously risks undermining a "rule of law" ethos in the internal conduct of executive branch affairs. ${ }^{15}$ Therefore, those inclined to read the Constitution in a less historicized, more values-oriented way need to consider seriously whether categorical separationism can be squared with the Constitution's obvious allegiance to "rule of law" values.

Categorical separationism has been touted, however, as having another particular virtue-a virtue exemplified, according to its proponents, by the $\mathrm{RB}$ regulatory review system it helped sustain. That virtue is the promotion of political accountability. ${ }^{16}$ The purpose of this article is to examine that claim in light of the competing RB and Clinton models of presidential regulatory oversight. My thesis is that the Clinton model of regulatory oversight, if implemented in the spirit that animates the prose of Executive Order No. 12,866, promises a significant gain in political accountability. In essence, its promised diffusion of authority would not weaken accountability, but strengthen it. To see why that is so requires a brief comparison of the two models and reflection on actual experience under the Council on Competitiveness. But it also necessitates some discussion of the very concept of "political accountability" that is

14. The originalist case against categorical separationism is presented comprehensively in Lessig and Sunstein, supra note 1, at 12-84. Other recent scholarship along similar lines includes Gerhard Casper, An Essay in Separation of Powers: Some Early Versions and Practices, 30 WM. \& MARY L. Rev. 211 (1989); William B. Gwyn, The Indeterminacy of the Separation of Powers in the Age of the Framers, 30 WM. \& MARY L. Rev. 263 (1989); William B. Gwyn, The Indeterminacy of the Separation of Powers and the Federal Courts, 57 Geo. WASH. L. Rev. 474 (1989); Peter M. Shane, Independent Policymaking and Presidential Power: A Constitutional Analysis, 57 Geo. WASH. L. Rev. 596 (1989); and Charles Tiefer, The Constitutionality of Independent Officers as Checks on Abuses of Executive Power, 63 B.U. L. REv. 59, 90 (1983).

15. Shane, supra note 4 , at $381-405$.

16. See Calabresi, supra note 1 , at 47 ; Lessig \& Sunstein, supra note 1; at 94 , at 102-03. 
more precise and detailed than what frequently is offered by enthusiasts of the categorical vision of separation of powers.

\section{CATEGORICAL SEPARATIONISM AT WORK: PRESIDENT BUSH'S COUNCIL ON COMPETITIVENESS}

In analyzing separation of powers issues, it is important to recall that there is no practical requirement that government institutions fully implement whatever theories of government are privately favored by those in control. Congress members may be persuaded of their near-exclusive authority to establish domestic economic policy, yet generously vest authority in administrators to perform that very function. The President, in turn, may share information freely concerning his policy deliberations despite a principled conviction that he is privileged to withhold it. ${ }^{17}$ In regulatory oversight, however, the Bush Administration did practice what it preached. It purveyed an official constitutional doctrine of plenary presidential authority to control bureaucratic activity, and, to an unprecedented degree, it centralized regulatory oversight in the White House.

The institution that ultimately spearheaded centralized oversight under the Bush Administration was the President's Council on Competitiveness. ${ }^{18}$ In June $1990,{ }^{19}$ President Bush assigned to that Council, by memorandum, the tasks of regulatory oversight formerly vested by President Reagan in a "Task Force on Regulatory Relief." 20 The Council seemingly perceived its role not merely as one of

17. I have noted earlier that, for these reasons, "separation of powers theory can provide only an incomplete prediction of actual government practice." Shane, supra note 4 , at 376.

18. President Bush originally announced formation of the Council in February, 1989 , as an inter-agency policy forum to review regulatory and other issues bearing on competitiveness. It was then described as "continuing" the work of the predecessor Task Force on Regulatory Relief. Building a Better America, Message from President George Bush to Congress, 25 Weekly Comp. Pres. Doc. 177, 184 (Feb. 9, 1989).

19. Office of the White House Press Secretary, Statement by the Press Secretary (June 15, 1990) (on file with author).

20. Exec. Order No. 12,291, 3 C.F.R. 127, 131 (1981), reprinted in 5 U.S.C. $\S 601$ (1988). 
reacting to agency proposals for regulation. The Council also took the initiative in identifying controversial areas of regulatory activity on which to focus its sustained attention. ${ }^{21}$

No executive order or other formal document "chartered" the Council on Competitiveness. The sole public document marking its establishment and structure was a "Fact Sheet" released in April 1989, by the Office of the Vice-President. ${ }^{22}$ There is no indication that, while in operation, the Council followed regular procedures, published or otherwise. It had no formal or informal agreement with Congress over legislative access to the documentation of its deliberative contributions. ${ }^{23}$ It established no controls on the degree or nature of its substantive contacts with outside interests. $^{24}$ The Council functioned chiefly not through its members-all presidential advisers, cabinet members, or designated representatives from particular agencies-but through the personal staff of the Vice-President. ${ }^{25}$ By interagency memo, it asserted its jurisdiction over:

not only regulations that are published for notice and comment, but also strategy statements, guidelines, policy manuals, grant and loan procedures, Advance Notices of Proposed Rulemaking, press releases and other documents announcing or implementing regulatory policy that affects the public. ${ }^{26}$

Given the Council's limited resources, the percentage of actual activities the Council could review was presumably quite small compared to the entire regulatory output of the

21. Bob Woodward \& David S. Broder, Quayle's Quest: Curb Rules, Leave "No Fingerprints," WASH. Post, Jan. 9, 1992, at A1, A17 (describing Council's role in a dispute with EPA over the regulatory definition of protected "wetlands").

22. The Vice President's Office, Office of the Press Secretary, Fact Sheet on the Council on Competitiveness (Apr. 12, 1989) (on file with author).

23. The Role of the Council on Competitiveness in Regulatory Review: Hearing Before the Committee on Governmental Affairs, 102d Cong., 1st Sess. 4-5 (1991) [hereinafter Glenn Hearings] (remarks of Senator Glenn).

24. Kirk Victor, Quayle's Quiet Coup, 23 NAT'L J., 1676, 1678 (1991); Michael Kranish, The Remaking of Dan Quayle, Boston Globe, Nov. 13, 1991, at 1, 16.

25. Kranish, supra note 24 , at 1, 16; Woodward \& Broder, supra note 21 , at A16.

26. Memorandum for Heads of Executive Departments and Agencies From the Vice President re: Regulatory Review Process, at 1 (Mar. 22, 1991) (on file with author). 
federal executive. Nonetheless, according to the Vice-President's self-expressed mandate, there was virtually no policy making activity that the Council regarded as categorically beyond its reach. ${ }^{27}$

A number of political circumstances coalesced between 1990 and 1992 to give the Council special policy making prominence. First, contrary to President Bush's deregulatory rhetoric, ${ }^{28}$ the Bush Administration entered 1990 and 1991 with a record of significant increases in the number of new regulations being issued. ${ }^{29}$ Given the sensitivity of that activity to the business community, plus the Vice-President's widely acknowledged need for enhanced political credibility, the Council provided the Vice-President a significant forum through which to demonstrate his substantiveness and his clout. ${ }^{30}$

Second, the Office of Management and Budget (OMB) regulatory review process got caught in a crossfire over the 1989 reauthorization of the Paperwork Reduction Act. ${ }^{31}$ That statute authorized the Office of Information and Regulatory Affairs (OIRA), which dominated the regulatory review effort under the Reagan Administrations and through the first half of the Bush Administration..$^{32}$ With the statutory authorization for funding OIRA set to expire, critics sought to insert into the reauthorization bill a set of procedural constraints for OIRA regulatory review. These included comprehensive "logging" requirements for all

27. Id.

28. See, e.g., Memorandum on Reducing the Burden of Government Regulation, 28 WeEkLy Comp. Pres. Docs. 231, 232 (Jan. 28, 1992).

29. Victor, supra note 24, at 1677; Robert Pear, In Bush Presidency, the Regulators Ride Again, N.Y. TiMES, Apr. 28, 1991, \& 4, at E5 (citing 17\% growth between 1989 and 1991 in the number of new agency rules being developed); Jonathan Rauch, The Regulatory President, 23 NAT'L J. 2902 (1991). The political sensitivity of the volume of regulation led President Bush to declare a 90-day election year moratorium on the issuance of new regulations, Memorandum on Reducing the Burden of Government Regulation, 28 Weekly Comp. Pres. Docs. 231, 232 (Jan. 28,1992 ), which he later extended an additional 120 days, Memorandum on Implementing Regulatory Reforms, 28 WeekLy Comp. Pres. Docs. 707, 728, 729 (Apr. $29,1992)$.

30. See generally Woodward \& Broder, supra note 21; Victor, supra note 24.

31. Percival, supra note 7, at 154-55.

32. Harold H. Bruff, Presidential Management of Agency Rulemaking, 57 GEO.

WASH. L. Rev. 533, 549, 557-59 (1989). 
OMB activities and communications relating to review, the imposition of deadlines for the conduct of reviews, and a requirement for OMB to explain in writing its reasons for suggesting changes in any proposed regulation. When OMB threatened to recommend a veto of any such requirements, Richard Darman, the director of OMB, and Rep. John Conyers, Chair of the House Government Operations Committee, reached a "sidebar" agreement to delete the statutory requirements in return for an OMB promise to implement the proposed changes administratively. ${ }^{33}$ Although the Darman-Conyers pact appeared to clear the path for House support of reauthorization, the Administration informed Rep. Conyers that it could not support the Darman deal because its provisions "would seriously interfere with the president's constitutional duty to supervise the Executive Branch." 34

In retaliation, the Democratic Congress refused either to reauthorize OIRA or to confirm a presidential appointee to succeed Wendy Gramm, who had departed as OIRA Administrator in 1989. As a consequence, OIRA lacked an advice-and-consent appointee to wield its authority over executive agencies. Although OIRA continued to operate its regulatory review operation without an express statutory charter, the Council on Competitiveness stepped in to fill the political void and to set the tone of regulatory review in a way that OIRA could not. ${ }^{35}$

Outside commentators have credited Allan B. Hubbard, the Council's executive director, with significantly institutionalizing the Council's regulatory review operation. ${ }^{36}$ Hubbard's appointment provoked criticism, however, from Congress and from environmentalists because, as partowner of an Indiana chemicals company and a significant

33. Dumas, Agreement on OMB Authority to Accompany House Bill, 48 Cong. Q. WKLY. REP. 836 (1990).

34. Dumas, White House Pulls the Rug Out on Regulatory Review Deal, 48 Cong. Q. WKLY. ReP. 1475 (1990). For additional background, see Dumas, Congress or the White House: Who Controls the Agencies?, 48 CONG. Q. WKLY. REP. 1130 (1990).

35. See David Clarke, Point of Darkness, The Envtl. F., Jan./Feb., 1992, at 28, 33, for a decidedly pro-environmentalist perspective on this point.

36. Victor, supra note 24, at 1677; Woodward \& Broder, supra note 21, at A16. 
holder of utilities stocks, he was thought to have both financial interests and ideological predispositions hostile to the environmental regulations that occupied most of the Council's agenda. ${ }^{37}$

There is no doubt the Council had significant impact on the content of regulatory policy making. As summarized by one recent commentator, the Council "convinced agency heads to weaken, and in some cases eliminate, regulations relating to commercial aircraft noise, the protection of wetlands, mandatory recycling, and air pollution." 38

Its impact is well illustrated by the Environmental Protection Agency's (EPA) experience in issuing regulations under the Clean Air Act Amendments of 1990 to limit the effect of new municipal incinerators as sources of air pollution. Among other things, the EPA originally proposed to:

require[ ] operators of [such] new sources of air pollution to achieve a twenty-five per cent reduction by weight of unprocessed waste by separating out some or all of the following recoverable/recyclable materials: paper and paperboard combined; ferrous materials; nonferrous metals; glass; plastics; household batteries; and yard waste. ${ }^{39}$

EPA would further have required the recycling of all leadacid batteries - the source of 60 percent of the lead in U.S. garbage ${ }^{40}$-and prohibited their incineration by municipal incinerators. ${ }^{41}$ These proposals were based on three costbenefit studies with which the Council on Competitiveness disagreed. ${ }^{42}$

37. Philip J. Hilts, House Panel Plans Inquiry Into Vice President's Staff, N.Y. Times, Nov. 22, 1991, at A14; Philip J. Hilts, Lawmakers Query Panelist's Ethics, N.Y. Times, Dec. 6, 1991, at A15; Philip J. Hilts, Quayle Returns Critics' Fire on Conflict of Interest, N.Y. Times, Dec. 12, 1991, at B18; Philip J. Hilts, Quayle Aide Faces New Conflict Charge, N.Y. Times, June 18, 1992, at B12.

38. DeWitt, supra note 7, at 762-63.

39. New York v. Reilly, 969 F.2d 1147, 1149 (D.C. Cir. 1992) (emphasis in the original).

40. Clean Air Act Implementation (Part I): Hearings Before the Subcommittee on Health and the Environment of the House Comm. on Energy and Commerce, 102d Cong., 1st Sess. 4-5 (1991) (statement of Rep. Sikorski).

41. New York v. Reilly, 969 F.2d at 1149.

.42. Victor, supra note 24, at 1679. 
The Council persuaded EPA to change the agency's view regarding the merits of the waste separation proposal. EPA abandoned its waste separation requirement because of its revised conclusion that "emissions reductions resulting from materials separation were not only difficult to quantify but were in fact relatively small." ${ }^{43}$ The D.C. Circuit subsequently determined that EPA had sufficient support in the record to justify this change in view as nonarbitrary. ${ }^{44}$

As paraphrased by the D.C. Circuit, the Council also had argued to EPA that EPA's waste separation plan "would violate principles of federalism because waste management is traditionally a state and local concern," and would not impose a "standard of performance" as authorized by the Clean Air Act, because the rule would set "a strict standard rather than allowing flexibility in meeting a particular goal."45 The D.C. Circuit did not rule on these arguments because EPA did not rest its final rule upon them. ${ }^{46}$

The D.C. Circuit did, however, invalidate EPA's decision not to ban the incineration of lead acid batteries. Public records are not available to substantiate how much of EPA's rationale for retreat emanated from the Council, but it is reasonable, given the political context, to infer a close relationship between the thinking of the Council and the rethinking by EPA. As recounted by the D.C. Circuit:

The Agency offered three reasons for its decision to omit the ban: (1) commenters questioned whether it would be possible to achieve 100 percent compliance; (2) the Resource Conservation and Recovery Act includes strict provisions against the burning of lead-acid batteries; and (3) EPA is considering a comprehensive approach to recycling lead-acid batteries under section 6 of the Toxic Substances Control Act. ${ }^{47}$

As the Court concluded, EPA's first reason utterly failed to explain abandoning a $100 \%$ ban for no limit at all, and its

43. New York v. Reilly, 969 F.2d at 1151.

44. Id.

45. Id. at 1152 n.9.

46. Id.

47. Id. at 1153 . 
further reasons offered no rationale for failing to fulfill an express Clean Air Act mandate to regulate new sources of air pollution. ${ }^{48}$

Among the Council's other most controversial deregulatory initiatives was vetoing EPA's proposed implementation of a Clean Air Act requirement for industry to secure state permits to increase emissions of any pollutant. ${ }^{49}$ Although the EPA proposal seemed to track closely the logic of the statute, ${ }^{50}$ the Competitiveness Council successfully urged a change under which any company could significantly increase its emission of a pollutant beyond its current permit levels simply by notifying state regulators of an intent to do so in 7 days. ${ }^{51}$ This approach effectively circumvented both EPA's express statutory authority to object to particular applications for permit applications, as well as a legislatively implied notice and comment period. ${ }^{52}$ Such was also the conclusion of EPA's General Counsel, expressed in a written opinion,,$^{53}$ which was essentially over-

48. Id.

49. Claudia O'Brien, White House Review of Regulations Under the Clean Air Act Amendments of 1990, 8 J. EnvTL. L. \& LitiG. 51, 80-93 (1993).

50. Under the Clean Air Act Amendments of 1990, it is unlawful for operators of those sources of pollution covered by the Act to operate such sources "except in compliance with a permit issued by a [designated] permitting authority . . ." 42 U.S.C. $\S 7661$ a(a) (Supp. 1992). The Amendments contemplate that a "permitted facility" may, however, make changes:

without requiring a permit revision, if the changes are not modifications under any provision of subchapter I of this chapter and the changes do not exceed the emissions allowable under the permit ... [p]rovided $[t]$ hat the facility provides the Administrator and the permitting authority with written notification in advance of the proposed changes which shall be a minimum of 7 days ....

42 U.S.C. $\S 7661 \mathrm{a}(\mathrm{b})(10)$ (Supp. 1992). Any change not covered by this provision would require an application for an amended permit, which would trigger requirements that the new permit application be transmitted to the EPA Administrator, as well as to any contiguous affected states. 42 U.S.C. $\$ 7661 \mathrm{~d}(\mathrm{a})$ (Supp. 1992). The Amendments further permit "any person" to petition EPA to object to a permit, 42 U.S.C. $\$ 7661 d$ (b) (Supp. 1992), logically implying that members of the public are to be afforded timely notice of pending permit applications.

51. O'Brien, supra note 49 , at $92-93$.

52. 42 U.S.C. $\$ 7661 \mathrm{~d}(\mathrm{~b})$ (Supp. 1992).

53. Letter from E. Donald Elliott, Assistant Administrator and General Counsel, Environmental Protection Agency, to William G. Rosenber, Assistant Administrator for Air and Radiation, re: Procedural Requirements for "Minor Permit Amendments" Under Title V of the Clean Air Act Amendments of 1990 (Aug. 16, 1991), reprinted in Glenn Hearings, supra note 23, at 220-25. 
ruled post hoc by a Justice Department legal opinion issued after EPA was forced to change its regulatory approach..$^{54}$

The pattern of anti-environmental changes achieved through Council intervention in other regulatory proposals is entirely consistent with these examples. The Council helped to derail an EPA effort to reduce sulphur dioxide emissions from the Navajo Generating Station, which, among other things, had obscured the view of Grand Canyon. ${ }^{55}$ The Council tried to press upon EPA a revised definition of protected "wetlands," which, by one estimate, would have lowered protections on one-third of American wetlands, as earlier defined, including a majority of forested wetlands. $^{56}$ The Council intervened to persuade the Federal Aviation Administration to relax its requirements for phasing out noisy aircraft under the Airport Noise and Capacity Act of $1990 .^{57}$

Such was the regulatory oversight system dedicated most faithfully to a categorical separation of powers philosophy that, in turn, was touted as advancing the cause of accountability. But even without careful parsing, the record suggests obvious accountability issues. First, it was the conclusion of the most extensive journalistic study of the Council that it intervened in "dozens of unpublicized controversies over important federal regulations, leaving what vice presidential aides call 'no fingerprints' on the results of its interventions." 58 The White House's efforts to avoid public disclosure of its oversight activity took multiple forms: resisting FOIA disclosure of documents belonging to President Reagan's Task Force on Regulatory Relief on the ground that the Task Force (and, by implication, the Council) was not a covered "agency";59 resisting Congres-

54. O'Brien, supra note 49 , at $92-93$.

55. Id. at 75-76; Victor, supra note 24 , at 1678 .

56. Christine Triano \& Nancy Watzman, All the Vice President's Men: How the Quayle Council on Competitiveness Secretly Undermines Health, Safety, and Environmental Programs, 9-11 (1991), reprinted in Glenn Hearings, supra note 23, at 297, 314-16; Woodward \& Broder, supra note 21, at A17.

57. DeWitt, supra note 7, at 762-63 n.11; Woodward \& Broder, supra note 21 , at A16-17.

58. Woodward \& Broder, supra note 21 , at A1.

59. Meyer v. Bush, 981 F.2d 1288 (D.C. Cir. 1993). 
sional access to information about the Council beyond published fact sheets and the testimony of individuals who did not participate in Council deliberations; ${ }^{60}$ keeping decisions at staff level to shield them from the greater publicity that would likely follow cabinet level involvement. ${ }^{61}$ Intriguingly, only one Council decision-pressuring EPA on pollution permit modifications-ever escalated to actual presidential involvement; ${ }^{62}$ the usual, albeit tacit, rule was to avoid appeals to the President wherever possible. ${ }^{63}$ It would not seem unrealistic that behind this approach lay a desire to buffer the President from criticism for Council policies, especially given a campaign promise to be the "environmental president." ${ }^{4}$ That would, of course, be the opposite of accountability.

The covertness of the Council's approach is troubling not only because of its seeming inconsistency with customary norms of regulatory process, ${ }^{65}$ but also because evidence suggests extraordinary access to the Council for special business interests. The Council's recommended modifications to EPA's permit amendment regulations were essentially identical to suggestions earlier made to the EPA by Indiana-based pharmaceutical company Eli Lilly, the Pharmaceutical Manufacturers Association, and the Motor Vehicles Manufacturers Association. ${ }^{66}$ One of the Vice President's closest personal advisers, though not on the Council, was Mitch Daniels, former political director in the Reagan White House and an Eli Lilly vice president. ${ }^{67}$

60. See Letter of Allan B. Hubbard, Executive Director, Council on Competitiveness, to the Honorable John Glenn, U.S. Senate (Apr. 25, 1991), reprinted in Glenn Hearings, supra note 23, at 283-84; Letter of Frederick D. McClure, Assistant to the President for Legislative Affairs, to the Honorable John Glenn, U.S. Senate (Nov. 14, 1991), reprinted in Glenn Hearings, supra note 23, at 341.

61. Woodward \& Broder, supra note 21, at A16.

62. O'Brien, supra note 49 , at 92.

63. Woodward \& Broder, supra note 21, at A16.

64. Susan Mandel, Competitiveness Role Raises Quayle's Profile, INvesToR's DAILY, Aug. 13, 1991, at 1.

65. DeWitt, supra note 7, at 778-88.

66. Michael Weisskopf, Writing Laws is One Thing-Writing Rules is Something Else, Wash. Post Nat'l WKLy. EdITION, Sept. 30-Oct. 6, 1991, at 31; Jim Sibbison, Dan Quayle, Business's Backdoor Boy, 253 The Nation 141, 160 (1991).

67. Kranish, supra note 24 , at $16,17$. 


\section{EXECUTIVE ORDER NO. 12,866: REINVENTING REAGAN-BUSH GOVERNMENT}

Although the Council on Competitiveness provided the political backdrop to President Clinton's regulatory reform efforts, it did not supply the model. Instead, both the structure and strategy of President Clinton's Executive Order No. 12,866 have obvious links to President Reagan's Executive Order No. 12,291,68 under which OIRA conducted regulatory oversight even through the Bush Administration. Both orders commence with statements of overall presidential goals and with principles of regulatory policy that the orders directly impose on the agencies within their purview. Both orders coordinate centralized regulatory review through the Office of the Vice President and the Office of Management and Budget. Each contemplates both a general regulatory planning process for individual agencies, plus separate regulatory impact analyses as a tool for managing the oversight process for certain significant regulations. Neither order purports to deprive any agency of decision making power that Congress has vested in the agency.

Within this common framework, however, there exist truly significant differences. These differences render the Clinton regulatory review process-at least on paper-less biased against regulation, more consultative, more accessible, and more deferential to policy making by individual agencies. On its face, the resulting system is more susceptible to "checking and balancing" by Congress and the courts.

\section{A. Presidential Objectives}

President Reagan stated the objectives underlying Executive Order No. 12,291 in succinct and, with one exception, generally nonsubstantive terms:

to reduce the burdens of existing and future regulations, increase agency accountability for regulatory actions, provide for presidential oversight of the regulatory pro-

68. Exec. Order No. 12,291, 3 C.F.R. 127 (1981), reprinted in 5 U.S.C. $\S 601$ (1988). 
cess, minimize duplication and conflict of regulations, and insure well-reasoned regulations. ${ }^{69}$

The only hint of genuinely substantive regulatory policy in this preamble is the desire to reduce regulatory "burdens," which foreshadows the subsequent RB deregulatory emphasis on cost-benefit analysis.

Executive Order No. 12,866 reaffirms the value commitments of the 12,291 preamble, but adds others:

The American people deserve a regulatory system that works for them, not against them: a regulatory system that protects and improves their health, safety, environment, and well-being and improves the performance of the economy without imposing unacceptable or unreasonable costs on society; regulatory policies that recognize that the private sector and private markets are the best engine for economic growth; regulatory approaches that respect the role of State, local, and tribal governments; and regulations that are effective, consistent, sensible, and understandable. ${ }^{70}$

Conspicuous in this prose is acceptance of a positive case for regulation. It is conceived that a regulatory system can "protect[] and improve[] . . . health, safety, environment, and well-being and improve[ ] the performance of the economy . . . " Undue burdens are decried as in 12,291; there should be no "unacceptable or unreasonable costs on society." But costs are, by implication, not unreasonable if a regulation efficiently facilitates an important social goal.

There are additional ways in which the Clinton preamble plainly seeks to distance itself from a philosophy it tacitly imputes to $\mathrm{RB}$ regulatory review:

[ $t$ ] he objectives of this Executive order are to enhance planning and coordination with respect to both new and existing regulations; to reaffirm the primacy of Federal agencies in the regulatory decision-making process; to restore the integrity and legitimacy of regulatory review and oversight; and to make the process more accessible and open to the public. In pursuing these objectives, the regulatory process shall be conducted so as to meet

69. Id.

70. Exec. Order No. 12,866, 3 C.F.R. 638, 638 (1993), reprinted in 5 U.S.C. $\S 601$ (Supp. 1993). 
applicable statutory requirements and with due regard to the discretion that has been entrusted to the Federal agencies. ${ }^{71}$

The apparent negative implications of the italicized phrases are that earlier Administrations had (1) compromised the decision making primacy of federal agencies, (2) jeopardized the integrity and legitimacy of regulatory review, and (3) cloaked regulatory oversight in too much secrecy. Reasserting the primacy of individual agencies and opening regulatory policy making to public scrutiny are two strategies, which, if implemented, could significantly diffuse effective power over regulatory decision making within the executive branch.

\section{B. Mandatory Principles of Regulation}

Both the Reagan and Clinton orders move beyond a hortatory preamble statement of general goals to specific principles that the respective Presidents would require agencies to follow to the extent otherwise permitted by law. The essential commands of the Reagan order are easily summarized: to regulate only where regulatory benefits outweigh costs, and to choose regulatory means that minimize the net cost of the administrative initiative. ${ }^{72}$ There is little elaboration in the order as to how such decisions shall be made.

The Clinton order focuses on a similar mandate, but describes it with greater nuance. The section on "regulatory philosophy" purportedly limits the occasions for regulation, but does so in a way that rhetorically acknowledges the frequent legitimacy of regulation:

Federal agencies should promulgate only such regulations as are required by law, are necessary to interpret the law, or are made necessary by compelling public need, such as material failures of private markets to protect or improve the health and safety of the public,

71. Id. (emphasis added).

72. Exec. Order No. 12,291, 3 C.F.R. 127, 128 (1981), reprinted in 5 U.S.C. $\S 601$ (1988). 
the environment, or the well-being of the American people. $^{73}$

Although echoing the earlier order's call for cost sensitivity, the Clinton order cautions against an overreliance on "hard variables":

Costs and benefits shall be understood to include both quantifiable measures (to the fullest extent that these can be usefully estimated) and qualitative measures of costs and benefits that are difficult to quantify, but nevertheless essential to consider. ${ }^{74}$

The order explicitly articulates a number of regulatory benefits that are not readily monetizable:

[I]n choosing among alternative regulatory approaches, agencies should select those approaches that maximize net benefits (including potential economic, environmental, public health and safety, and other advantages; distributive impacts; and equity). . . . ${ }^{75}$

The Clinton order gives additional guidance on the analytic process by which its philosophy is to be implemented. Prior to issuing any new regulations, agencies are instructed to consider whether administrative objectives may be accomplished through alternatives to new regulation, including the modification of existing schemes. ${ }^{76}$ Yet, even this direction to seek cost-effectiveness is modified by an analysis facially more complex than straightforward bottom-line analysis:

In [designing regulations in the most cost-effective manner], each agency shall consider incentives for innovation, consistency, predictability, the costs of enforcement and compliance (to the government, regulated entities, and the public), flexibility, distributive impacts, and equity. ${ }^{77}$

There are also specific requirements for agencies "to the extent feasible, [to] specify performance objectives, rather than specifying the behavior or manner of compliance that

73. Exec. Order No. 12,866, 3 C.F.R. 638, 638-39 (1993), reprinted in 5 U.S.C. $\S 601$ (Supp. 1993).

74. Id. at 639 .

75. Id.

76. Id. at 646 .

77. Id. at 639 . 
regulated entities must adopt," [to] seek views of appropriate State, local, and tribal officials before imposing regulatory requirements that might significantly or uniquely affect those governmental entities." 79

Institutionally, these directives have significance beyond the obvious replacement of a conservative Republican regime with an Administration of moderate-to-liberal Democrats. Because agencies issue regulations almost exclusively pursuant to congressional mandate, the President's rhetorical acceptance of a potential positive role for regulation immediately aligns his policy stance more closely with the stance of Congress, which must have envisioned a positive role for regulation in authorizing the regulatory process in the first place. Moreover, the more eclectic set of presidentially approved regulatory concerns-including "public health and safety, and other advantages; distributive impacts; and equity"-creates a value structure more readily aligned with the policies underlying a host of regulatory statutes, none of which necessarily embodies the procrustean cost-benefit orientation of the RB approach. The broader framework that the order endorses for assessing a regulation's appropriateness would additionally support a broader-based, less bounded consultation both within and outside the Adminstration as to the justification for any particular regulatory initiative.

\section{General Regulatory Planning}

Both the Reagan and Clinton orders envision a general regulatory planning process. Executive Order 12,291 mandated only a portion of that process, which President Reagan later amplified in. Executive Order No. 12,498. ${ }^{80}$ The key planning tool under 12,291 was the "regulatory agenda," earlier mandated by President Carter. Order No. 12,291 required each agency to publish a semiannual schedule of "proposed regulations that the agency has issued or

78. Id.

79. Id. at 640 .

80. Exec. Order No. 12,498, 3 C.F.R. 323 (1985), reprinted in 5 U.S.C. $\S 601$ (1988). 
expects to issue, and currently effective rules that-are under agency review. ..."81 The agenda was to include a summary of each rule, "an approximate schedule for completing action on any major rule for which the agency has issued a notice of proposed rulemaking," and information on contacting agency officials knowledgeable about the matters listed. ${ }^{82}$

Executive Order No. 12,498, issued in early 1985, just prior to the advent of the second Reagan Adminstration, ordered a yet more full-blown regulatory planning process. Each agency was required to develop and submit in draft to OMB an annual "Regulatory Program." The order empowered the OMB director to review the draft programs for consistency with Administration policies, and to identify further "regulatory or deregulatory actions as may, in his view, be necessary in order to achieve such consistency." 83 The President or a cabinet council would resolve any disagreements over such recommendations. ${ }^{84}$ Otherwise, the agency head would submit the agency's final regulatory program for publication; the Director, before issuing, could then circulate it for further interagency comment and consultation. ${ }^{85}$ Agency heads were finally obligated to notify the Director immediately of any regulatory actions intended during the next year that had not previously been submitted for review. ${ }^{86}$

Executive Order No. 12,866 substitutes for both of these Reagan orders a planning process that is in various ways more fluid and more elaborate. The threshold difference, however, lies in the very range of agencies required to participate. The Reagan orders applied to every agency covered by the fairly comprehensive definition of "agency" in the Paperwork Reduction Act, excluding those listed in

81. Exec. Order No. 12,291, 3 C.F.R. 127, 130 (1981), reprinted in 5 U.S.C. $\S 601$ (1988).

82. Id.

83. Exec. Order No. 12,498, 3 C.F.R. 323, 324 (1985), reprinted in 5 U.S.C. $\S 601$ (1988).

84. Id.

85. Id.

86. Id. at 324-25. 
that Act as "independent regulatory agencies." 87 The regulatory analysis provisions of the Clinton order have the identical purview, ${ }^{88}$ but the general planning system extends further, embracing the independent agencies, whom the Reagan Administration had only invited to participate voluntarily in the 12,291 regulatory review process. ${ }^{89}$

The Clinton planning process is prefaced by a general allocation of authority to those whom the order treats as the key "players" in regulatory planning and review. First, the agencies themselves are described as "responsible for developing regulations and assuring that the regulations are consistent with applicable law, the President's priorities, and the principles set forth in [the Clinton executive] order." 90 OMB is charged with the "coordinated review of agency rulemaking," both to help insure, as do the agencies, that regulations are consistent with both law and the President's policies, but also to see "that decisions made by one agency do not conflict with the policies or actions taken or planned by another agency." 91 The Vice President is designated "the principal advisor to the President" on regulatory matters, and is ordered to "coordinate the development and presentation of recommendations concerning, regulatory policy, planning, and review." 92

Within this framework, the Clinton order envisions an annual "planning cycle," early in which the Vice President shall convene a meeting of the so-called "Advisors,"

87. Exec. Order No. 12,291, 3 C.F.R. 127, 128 (1981), reprinted in 5 U.S.C. $\S 601$ (1988).

88. Exec. Order No. 12,866, 3 C.F.R. 638, 641 (1993), reprinted in 5 U.S.C. $\S 601$ (Supp. 1993).

89. Id. at 642 .

90. Id. at 640 .

91. Id.

92. Id.

93. Under the order, these include:

(1) the Director of OMB; (2) the Chair (or another member) of the Council of Economic Advisers; (3) the Assistant to the President for Economic Policy; (4) the Assistant to the President for Domestic Policy; (5) the Assistant to the President for National Security Affairs; (6) the Assistant to the President for Science and Technology; (7) the Assistant to the President for Intergovernmental Affairs; (8) the Assistant to the President and Staff Secretary; (9) the Assistant to the President and Chief of Staff to the Vice President; (10) the Assistant to the President and Counsel to the President; 
gether with the heads of agencies. The purpose of the meeting is "to seek a common understanding of priorities and to coordinate regulatory efforts to be accomplished in the upcoming year."94 As under the Reagan system, during the planning cycle each agency is required to prepare a "Unified Regulatory Agenda" and a "Regulatory Plan," with contents similar to those mandated in the earlier orders. ${ }^{95}$

Upon receiving an agency's Regulatory Plan, however, the Clinton order neither envisions an indefinite period for unilateral OMB review, nor bestows discretion over the Plan's interagency circulation to the Director. Instead, each agency is ordered to forward its annual plan to OMB's Office of Information and Regulatory Affairs by June 1; OIRA, in turn, is required in all cases to "circulate it to other affected agencies, the Advisors, and the Vice President." 96 The intended result is presumably a significant diffusion of official authority to raise issues about a plan, and a consequent reduction in OMB's exclusive power to secondguess agencies. The order permits any "agency head who believes that a planned regulatory action of another agency may conflict with its own policy or action taken or planned" to raise that issue with the issuing agency, the Advisors, and the Vice President. ${ }^{97}$ The Administrator of OIRA is likewise authorized to alert that same group if she "believes that a planned regulatory action of an agency may be inconsistent with the President's priorities or the principles set forth in [the] Executive order or may be in conflict with any policy or action taken or planned by another agency." 98

It is noteworthy that the circulation of the plan presumably leaves the initiating agency an opportunity to mobilize its allies, as well as to arouse its opponents, among

(11) the Deputy Assistant to the President and Director of the White House Office on Environmental Policy; and (12) the Administrator of OIRA.

Id. at 641 .
94. Id. at 642 .
95. Id. at $642-43$.
96. Id. at 643 .
97. Id.
98. Id. 
other agencies. Moreover, the order directs that "[t]he Plans developed by the issuing agency shall be published annually in the October publication of the Unified Regulatory Agenda."99 The italicized language and the absence of any reference in the order to the submission of a "draft plan," strongly suggests that OMB does not have authority to preclear or to stop publication of a plan that an agency is prepared to publish. ${ }^{100}$

The multilateral and highly consultative nature of the planning process that the order envisions is underscored emphatically by two additional provisions. The first is a mandate to the Administrator of OIRA to convene a Regulatory Working Group (RWG), including the heads of each agency with "significant domestic regulatory responsibility," plus the Advisors and the Vice President. ${ }^{101}$ The RWG is charged to meet at least quarterly in its role as:

a forum to assist agencies in identifying and analyzing important regulatory issues (including, among others (1) the development of innovative regulatory techniques, (2) the methods, efficacy, and utility of comparative risk assessment in regulatory decision-making, and (3) the development of short forms and other streamlined regulatory approaches for small businesses and other entities). ${ }^{102}$

Additionally, the Administrator of OIRA is required to "meet quarterly with representatives of State, local, and tribal governments to identify both existing and proposed regulations that may uniquely or significantly affect those governmental éntities," and to "convene, from time to time, conferences with representatives of businesses, nongovern-

99. Id. (emphasis added).

100. This inference is buttressed by Section 8 of the Clinton order, concerning the publication or issuance of regulatory actions. Id. at 648-49. In brief, that section requires agencies to delay the publication of "any regulatory action that is subject to review under section 6" of the order. Id. (emphasis added). Because regulatory plans are subject to review under section 4, not section 6, the negative implication of this provision is that agencies need not stay the publication of their plans pending OMB review or approval.

101. Id. at 643.

102. Id. This section further provides: "To inform its discussions, the Working Group may commission analytical studies and reports by OIRA; the Administrative Conference of the United States, or any other agency." 
mental organizations, and the public to discuss regulatory issues of common concern." 103 These provisions potentially regularize an influential form of public input at the regulatory planning stage that goes significantly beyond the notice-and-comment opportunities linked to individual regulatory proposals.

In designing its planning process, the drafters of the Clinton order apparently inferred an additional lesson from their predecessors. Executive Order 12,291 did no more about old regulations than (1) require agencies, in general terms, to "initiate reviews of currently effective rules in accordance with the purposes of this Order,"104 and (2) empower the OMB director to designate certain existing rules for regulatory analysis. ${ }^{105}$ In contrast, the new order requires each agency to submit to OIRA:

a program, consistent with its resources and regulatory priorities, under which the agency will periodically review its existing significant regulations to determine whether any such regulations should be modified or eliminated so as to make the agency's regulatory program more effective in achieving the regulatory objectives, less burdensome, or in greater alignment with the President's priorities and the principles set forth in [the] Executive order. ${ }^{106}$

Moreover, the RWG, and state, local, and tribal governments are asked to participate in the process of identifying outmoded regulations or rules otherwise in need of reform. ${ }^{107}$ The Vice President, in consultation with the Advisors, is authorized to:

identify for review by the appropriate agency or agencies other existing regulations of an agency or groups of regulations of more than one agency that affect a particular group, industry, or sector of the economy, or may

103. Id. at 643-44.

104. Exec. Order No. 12,291, 3 C.F.R. 127, 130 (1981), reprinted in 5 U.S.C. $\S 601$ (1988).

105. Id.

106. Exec. Order No. 12,866, 3 C.F.R. 638, 644 (1993), reprinted in 5 U.S.C. § 601 (Supp. 1993).

107. Id. 
identify legislative mandates that may be appropriate for reconsideration by the Congress. ${ }^{108}$

The obvious aim of this effort is to avoid subjecting to extensive review only new regulations that, of necessity, are most likely to reflect the most up-to-date information and policy thinking, while leaving untouched regulations that, equally of necessity, do not reflect current information or policy consultation.

\section{Regulatory Review.}

Most of the remainder of both the Reagan and Clinton orders is devoted to their respective review processes for individual regulations. The orders adopt virtually identical definitions for the "regulations" they cover. ${ }^{109}$ The Clinton order addititonally covers "regulatory actions," defined as:

any substantive action by an agency (normally published in the Federal Register) that promulgates or is expected to lead to the promulgation of a final rule or regulation, including notices of inquiry, advance notices of proposed rulemaking, and notices of proposed rulemaking. ${ }^{110}$

From this universe of administrative activity, each order then seeks to focus regulatory review only on regulations or regulatory actions that are "major" or "significant."

Here, the orders articulate a significant substantive difference. The Reagan order measured the significance of a regulation entirely in cost terms:

"Major rule" means any regulation that is likely to result in:

108. Id.

109. The only obvious difference is that both exclude from their coverage regulations that relate "to a military or foreign affairs function of the United States," except that the Clinton order carves out of this exception "procurement regulations and regulations involving the import or export of non-defense articles and services," which are made subject to the order. Compare Exec. Order No. 12,291, 3 C.F.R. 127 (1982), reprinted in 5 U.S.C. $\$ 601$ (1988) with Exec. Order No. 12,866, 3 C.F.R. 638, 641 (1993), reprinted in 5 U.S.C. $\$ 601$ (Supp. 1993).

110. Exec. Order No. 12,866, 3 C.F.R. 638, 641 (1993), reprinted in 5 U.S.C. $\S 601$ (Supp. 1993).

111. Exec. Order No. 12,291, 3 C.F.R. 127 (1981), reprinted in 5 U.S.C. $\$ 601$ (1988); Exec. Order No. 12,866, 3 C.F.R. 638, 641-42 (1993), reprinted in 5 U.S.C. $\S 601$ (Supp. 1993). 
(1) An annual effect on the economy of $\$ 100$ million or more;

(2) A major increase in costs or prices for consumers, individual industries, Federal, State, or local government agencies, or geographic regions; or

(3) Significant adverse effects on competition, employment, investment, productivity, innovation, or on the ability of United States-based enterprises to compete with foreign-based enterprises in domestic or export markets. ${ }^{112}$

Any rule falling within this Reagan order definition would be deemed "significant" under the Clinton order as well. ${ }^{113}$ But a regulation or regulatory action under the new order will also be deemed significant, and, hence, potentially subject to centralized review, if it could:

(1) Adversely affect in a material way ... the environment, public health or safety, or . . . tribal governments or communities;

(2) Create a serious inconsistency or otherwise interfere with an action taken or planned by another agency;

(3) Materially alter the budgetary impact of entitlements, grants, user fees, or loan programs or the rights and obligations of recipients thereof; or

(4) Raise novel legal or policy issues arising out of legal mandates, the President's priorities, or the principles set forth in this Executive order. ${ }^{114}$

Potentially, this coverage significantly softens the apparent anti-regulatory bias of the RB regulatory review process. A rule may now be reviewed if it could significantly hurt the environment, public health, or safety, or diminish the rights of individuals receiving government entitlements, grants, or loans. Excessive cost, in other words, is not the only "red flag" to arouse OMB's attention.

Beyond differences in the regulatory actions covered, the orders are similar, but not identical, in their strategy for

112. Exec. Order No. 12,291, 3 C.F.R. 127, 127-28 (1981), reprinted in 5 U.S.C. $\S 601$ (1988).

113. Exec. Order No. 12,866, 3 C.F.R. 638, 641-42 (1993), reprinted in 5 U.S.C. $\S 601$ (Supp. 1993).

114. Id. 
review. The key review mechanism under the Reagan order was the "Regulatory Impact Analysis" (RIA), which each agency was required to perform "in connection with every major rule."115 In the ordinary case ${ }^{116}$ - that is, rulemaking initiated by a notice of proposed rulemaking (NPRM) - each agency would prepare a preliminary RIA to accompany each NPRM and submit both to OMB at least 60 days prior to publication. ${ }^{117}$ A final RIA would accompany a final rule, both of which would be submitted to OMB 30 days prior to publication. ${ }^{118}$ The RIA would include, in essence, an assessment of a major rule's expected costs and benefits, and a description of alternative approaches that might be more cost-effective, but were not chosen. ${ }^{119}$

Although not using the RIA terminology, the Clinton order requires a similar analysis for all "significant regulatory actions," unless OIRA waives the requirement. ${ }^{120}$ OMB's capacity to use regulatory review for the indefinite delay of a regulatory action appears, however, to be substantially curtailed. The Reagan order authorized the OMB director or his designee (who turned out be the Administrator of OIRA) to review all proposed and final RIA's. ${ }^{121}$ Upon the request of the Director, an agency was required:

[to] consult with the Director concerning the review of a preliminary Regulatory Impact Analysis or notice of proposed rulemaking under this Order, and ... refrain from publishing its preliminary Regulatory Impact Analysis or notice of proposed rulemaking until such review is concluded. ${ }^{122}$

115. Exec. Order No. 12,291, 3 C.F.R. 127, 128 (1981), reprinted in 5 U.S.C. $\S 601(1988)$.

116. Somewhat different rules applied for rulemaking for which no NPRM was legally required, $i d$.; emergency rulemaking, $i d$. at 133; and regulations for which the review timetable would conflict with a statutory or judicial deadline, id.

117. Id. at 129.

118. Id.

119. Id.

120. Exec. Order No. 12,866, 3 C.F.R. 638, 645-46 (1993), reprinted in 5 U.S.C. $\S 601$ (Supp. 1993).

121. Exec. Order No. 12,291, 3 C.F.R. 127, 129 (1981), reprinted in 5 U.S.C. $\S 601$ (1988).

122. Id at at 129-30. 
Likewise:

Upon receiving notice that the Director intends to submit views with respect to any final Regulatory Impact Analysis or final rule, the agency shall ... refrain from publishing its final Regulatory Impact Analysis or final rule until the agency has responded to the Director's views, and incorporated those views and the agency's response in the rulemaking file. ${ }^{123}$

Absent from these provisions was a deadline for OMB either to complete its review of a proposed RIA or to submit its comments for a final rulemaking. The impact one might have predicted, a lengthy extension of the rulemaking process for any regulation opposed by OMB, seems to have occurred. ${ }^{124}$

The Clinton order, in contrast, includes a tight timetable within which a review process is to proceed. OMB is subject to strict deadlines at each stage of review, and, in reviewing any proposed or final regulatory action, is permitted to extend its process only "once by no more than 30 calendar days upon the written approval of the Director."125 Moreover:

[f]or each regulatory action that the Administrator of OIRA returns to an agency for further consideration of some or all of its provisions, the Administrator of OIRA [is required to] provide the issuing agency a written explanation for such return, setting forth the pertinent provision of this Executive order on which OIRA is relying. ${ }^{126}$

The requirement that OIRA focus its concerns in writing is a potentially significant mechanism for avoiding undue delay in regulatory review. The exercise of putting objections in writing may discipline $\mathrm{OMB}$ in lodging objections because it requires some precision of scope and explanation; when an objection is lodged, the agency will presumably also be better off by having clear notice where its analytical energies must be focused in order to satisfy OMB.

123. Id. at 130.

124. Bruff, supra note 32, at 565-68; Percival, supra note 7, at 156-61.

125. Exec. Order No. 12,866, 3 C.F.R 638, 647 (1993), reprinted in 5 U.S.C. $\S 601$ (Supp. 1993).

126. Id. 
The intent to prevent undue OMB-induced postponements of regulatory action is reinforced by the Clinton order's provisions concerning the publication of regulatory actions. As under Executive Order No. 12,291, agencies are not to publish regulatory actions subject to OIRA review until "the Administrator of OIRA notifies the agency that OIRA has waived its review of the action or has completed its review without any requests for further consideration." 127 However, unlike Executive Order No. 12,291, the new order provides that extended OIRA silence is tantamount to authorizing the agency to publish; agencies are entitled to go forward if "the applicable time period . . . expires without OIRA having notified the agency that it is returning the regulatory action for further consideration." 128 The intended consequence of these provisions is to render OMB more accountable in the discharge of its functions and to restore a more even balance of power between the agency and $\mathrm{OMB}$ in fine-tuning agency regulations.

\section{E. Sunshine Provisions.}

Yet another respect in which the Clinton order differs markedly from Excecutive Order No. 12,291 is in its codification of disclosure provisions and protections against $e x$ parte contacts. Both orders require agencies to make their regulatory analyses available to the public once the relevant regulatory action is published. ${ }^{129}$ The Clinton order, however, codifies certain disclosure measures voluntarily adopted by OMB during the Reagan Administrations, ${ }^{130}$ even though not required to do so by Executive Order No. 12,291. Moreover, Executive Order 12,866 adopts the sunshine measures mentioned earlier that were urged upon, but resisted by, the Bush Administration in a fight that led

127. Id. at 648 .

128. Id.

129. Exec. Order No. 12,291, 3 C.F.R. 127, 130 (1981), reprinted in 5 U.S.C. $\S 601$ (1988); Exec. Order No. 12,866, 3 C.F.R. 638, 646 (1993), reprinted in 5 U.S.C. $\S 601$ (Supp. 1993).

130. OMB agreed in 1986 to disclose draft notices of proposed rulemaking and final rules submitted for OMB review, together with any related correspondence between agency heads and OIRA. Bruff, supra note 32, at 582. See Exec. Order No. 12,866, 3 C.F.R. 638, 646, 648 (1993), reprinted in 5 U.S.C. $\$ 601$ (Supp. 1993). 
to Congress's refusal to reauthorize OIRA when its statutory mandate expired in $1990 .^{131}$

First, the Clinton order contains significant protections to insure that agencies are not subject to pressures from OMB based upon outside communications of which the agencies were never informed. Under Executive Order No. 12,866 , "[o]nly the Administrator of OIRA . . . is permitted within OMB to receive oral communications initiated by persons not employed by the executive branch of the Federal Government regarding the substance of a regulatory action under OIRA review."132 An agency representative is entitled to attend any "substantive" meetings between OIRA personnel and persons not employed by the executive branch regarding a regulatory action under review. ${ }^{133}$ With respect to such actions, OIRA is required to:

forward to the issuing agency, within 10 working days of receipt of the communication(s), all written communications, regardless of format, between OIRA personnel and any person who is not employed by the executive branch of the Federal Government, and the dates and names of individuals involved in all substantive oral communications (including meetings to which an agency representative was invited, but did not attend, and telephone conversations between OIRA personnel and any such persons). ${ }^{134}$

Moreover, the public is entitled to significant information about the review process, even while it is ongoing. OIRA is commanded to:

maintain a publicly available log that shall contain, at a minimum, the following information pertinent to regulatory actions under review:

(i) The status of all regulatory actions, including if (and if so, when and by whom) Vice Presidential and Presidential consideration was requested;

131. See supra text accompanying notes 31-34. OMB's current "logging" requirements appear at Exec. Order No. 12,866, 3 C.F.R. 638, 647-48 (1993), reprinted in 5 U.S.C. $\$ 601$ (Supp. 1993).

- 132. Exec. Order No. 12,866, 3 C.F.R. 638, 647 (1993), reprinted in 5 U.S.C. $\S 601$ (Supp. 1993).

133. Id.

134. Id. 
(ii) A notation of all written communications [between OIRA personnel and any person who is not employed by the executive branch] forwarded to an issuing agency ...; and

(iii) The dates and names of individuals involved in all substantive oral communications, including meetings and telephone conversations, between OIRA personnel and any person not employed by the executive branch of the Federal Government, and the subject matter discussed during such communications. ${ }^{135}$.

This log is to be supplemented with additional information once a regulatory action is published or the agency decides not to go forward. At that point, "OIRA shall make available to the public all documents exchanged between OIRA and the agency during the review by OIRA under this section." 136 This is a dramatic change of policy, given the scope of $\mathrm{RB}$ resistance to the disclosure of documents revealing the deliberative processes entailed in regulatory policy making.

\section{F. Conflict Resolution.}

A final significant area of difference between the two orders lies in the Clinton order's formalization of a process for conflict resolution in connection with regulatory review. Executive Order No. 12,291 did not expressly provide for any such mechanism. Its only hint-because the OMB Director was generally subjected to the supervision of a Presidential Task Force on Regulatory Relief-was that agencies caught at impasse with the Director could resort to the Task Force on appeal. While in existence, that Task Force was chaired by then-Vice President Bush, rendering the Vice President a potential intermediary in regulatory disputes. In fact, however, the Task Force was dormant from the middle of the first Reagan Administration until the late middle of the second Reagan Administration. ${ }^{137}$ There was thus no

135. Id. at 647-48.

136. Id. at 648.

137. Percival, supra note 7, at 152; Editorial, Bush Business, 244 THE NAtion 420 (1987). 
codified appeal route for an agency challenging OMB's resistance to its policy judgments. ${ }^{138}$

The Clinton order codifies just such a vice presidential role. In the event of issues "between or among agency heads or between OMB and any agency that cannot be resolved by the Administrator of OIRA," conflicts are to "be resolved by the President, or by the Vice President acting at the request of the President, with the relevant agency head (and, as appropriate, other interested government officials)." 139 Vice presidential and presidential consideration of such disagreements, however, "may be initiated only by the [OMB] Director, by the head of the issuing agency, or by the head of an agency that has a significant interest in the regulatory action at issue." ${ }^{140}$ The order underscores the limited range of persons authorized to invoke presidential or vice presidential review of regulation: "Such review will not be undertaken at the request of other persons, entities, or their agents." ${ }^{141}$ In light of the Council on Competitiveness experience, discussed above, the apparent message is clear: presidential or vice-presidential review is not to become a vehicle for special interests outside the government to acquire covert leverage over a policymaking process they cannot control through more generally available opportunities for public participation. Indeed:

[d] uring the Vice Presidential and Presidential review period, communications with any person not employed by the Federal Government relating to the substance of the regulatory action under review and directed to the Advisors or their staffs or to the staff of the Vice President shall be in writing and shall be forwarded by the recipient to the affected agency(ies) for inclusion in the public docket(s). When the communication is not in writing, such Advisors or staff members shall inform the

138. As of 1986, there appear to have been only two rules promulgated over OMB objection following consultation with the White House. Percival, supra note 7 , at 150 .

139. Exec. Order No. 12,866, 3 C.F.R. 638, 648 (1993), reprinted in 5 U.S.C. $\S 601$ (Supp. 1993).

140. Id.

141. Id. 
outside party that the matter is under review and that any comments should be submitted in writing. ${ }^{142}$

To date, not enough can be known about the operation of Executive Order No. 12,866 to be certain how great the contrast will prove to be between $\mathrm{RB}$ regulatory review and its successor. It is conspicuous, however, that the drafters of the order wanted to create impressions of greater consistency between the aims of regulatory review and the value structure animating Congress, greater deference to individual agencies as policy makers, and more openness in regulatory review. As discussed below, each of these aspects of the Clinton's approach arguably augurs well for political accountability, although they diffuse policy making influence and soften the seeming hierarchical rigidity of $R B$ oversight.

\section{POLITICAL ACCOUNTABILITY AND REGULATORY OVERSIGHT}

\section{A. What is Accountability?}

Some prominent champions of the categorical vision of separation of powers ${ }^{143}$ - and, indeed, even enthusiasts of somewhat more restrained versions of the so-called "unitary executive" 144 -insist that tighter White House coordination of executive policy making would increase the executive's "accountability." Those who read categorical separationism into the framers' intent insist that the framers' original accountability concerns dictate a strong version of the "unitary executive" as a constitutional mandate. ${ }^{145}$ Others, such as Professors Lessig and Sunstein, disavow this originalist interpretation. But Lessig and Sunstein pose an argument that the powerful potential contribution of the "unitary executive" to official accountability might nonetheless be sufficient to sustain a modernist "unitarian" read-

142. Id.

143. Steven G. Calabresi \& Kevin H. Rhodes, The Structuralist Constitution: Unitary Executive, Plural Judiciary, 105 HaRv. L. Rev. 1153 (1992).

144. Peter L. Strauss \& Cass R. Sunstein, The Role of the President in Informal Rulemaking, 38 Admin. L. REv. 181, 190 (1986).

145. Calabresi, supra note 1 , at 49. 
ing of the Constitution-one that yields, albeit on different intepretive premises, an equivalent constitutional mandate of highly centralized presidential control of administration. ${ }^{146}$

As I noted at the outset, however, the debate over the President's policy prerogatives and their relationship to accountability clearly has significance beyond disputes over constitutional interpretation. Just as frequently at issue in most recent discussions is which of various political control models Congress ought to follow as a matter of policy in designing administrative programs. ${ }^{147}$ Unfortunately, the competing positions in this debate-or, more accurately, what is truly at stake in the competing positions-does not lend itself to easy sound-bites.

In one sense, the debate seems to be about the comparative wisdom of following two fairly distinct models of President-bureaucracy relationship. Under one model, which we can call the "presidentialist" model, Congress is urged to exercise its own policy making discretion to structure a department or a decisional process in a way that maximizes the possibility for presidential review. Congress is, of course, entitled to make bureaucratic policy makers removable at the President's will, to subject certain decisions expressly to presidential review, or even, if it chooses, to authorize something like the OIRA regulatory review process as a statutory mandate. Following another model, however, typically called the "independent agency" model, Congress could alternatively use its discretion to structure an administrative program so that decision makers are relatively insulated from presidential politics. Common mechanisms for achieving such insulation include statutory protections for job tenure, requirements for the public "logging" of all agency communications relevant to a particular decision, or requirements for adjudicatory decision mak-

146. Lessig \& Sunstein, supra note 1, at 93-106.

147. See, e.g., Dellisa Ridgeway et al., Fourth Annual Conference on Administrative Law Panel on the Council on Competiveness and Regulatory Review: A "Kinder, Gentler" Approach to Regulation? 6 ADMIN. L.J. 639, $691-707$ (1993); Thomas O. Sargentich, The Administrative Process in Crisis-The Example of Presidential Oversight of Agency Rulemaking, 6 ADMin. L.J. 639, 710-20 (1993). 
ing. ${ }^{148}$ Given these alternatives, it becomes clear why probing the relationship between presidential authority and agency accountability is doubly relevant for enthusiasts of the unitary executive. Even if dispassionate analysis cannot yield a persuasive constitutional mandate for the presidential control model, it might at least persuade Congress to delegate presidential authority more generously on the ground that, as a normative proposition, strong presidential oversight of the bureaucracy is a good thing. ${ }^{149}$

But to think of the available alternative to "presidentialism" as independent agencies, though a common locution, is surely misleading. The heads of so-called independent agencies are still largely susceptible to presidential influence. This may be because Presidents choose the agency heads, or because presidential involvement in their budget processes is critical, or because such agencies still need presidential support for legislative initiatives, or simply because the President, because he is President, knows how to get attention. ${ }^{150}$ Moreover, despite Congress's obvious tools of influence vis-a-vis agencies, it operates within an institutional framework that categorically prohibits the legislative branch from actually implementing the laws of the United States. ${ }^{151}$. Thus, the more obviously

148. The variety of choices facing Congress in structuring new agencies is briefly surveyed in Jerry L. Mashaw, Richard A. Merrill \& Peter M. Shane, Admin. istrative Law: The American Public Law System 12-28 (3d ed. 1992).

149. Cf., Jerry L. Mashaw, Prodelegation: Why Administrators Should Make Political Decisions, 1 J.L. Econ. \& Organ. 81 (1985).

150. For discussions of independent agencies that view the phenomenon of independence skeptically, see Symposium: The Independence of Independent Agencies, 1988 Duke L.J. 215, 215-99 (1988).

151. Among recent Supreme Court decisions strongly rebuffing Congress's efforts to enter into what the Court deemed an actual administrative role are Buckley v. Valeo, 424 U.S. 1 (1976) (prohibiting direct Congressional appointments of persons charged with executing the laws); Bowsher v. Synar, 478 U.S. 714 (1986) (prohibiting any congressional role other than impeachment in the removal of persons charged with executing the laws); Immigration and Naturalization Serv. v. Chadha, 462 U.S. 919 (1983) (invalidating legislative veto); and Metropolitan Washington Airports Auth. v. Citizens for Abatement of Aircraft Noise, 501 U.S. 252 (1991) (invalidating participation by members of Congress on board of directors for regional airport authority). See also District of Columbia Fed'n of Civic Ass'ns v. Volpe, 459 F.2d 1231 (D.C. Cir. 1971) (vacating Secretary of Transportation's funding decision to determine if sustainable apart from influence of congressional committee chairman); Pillsbury Co. v. Federal Trade Comm'n, 354 F.2d 952 (5th Cir. 
Congress seeks to whittle its way into the actual processes of law administration, the more vulnerable its maneuvers to legal and political resistance become.

For these reasons, the alternative to "presidentialism" is not really agency policy independence or even "congressionalism." The real-world alternative is probably best described as "political pluralism."152 In the pluralist world, the President may still, within statutory limits, seek to influence the policy outcomes of administrative agencies. He is not, however, constitutionally guaranteed any dispositive "last say" in policy making that may legitimately and invariably trump the influence of other political forces.

Other commentators do not deny the pluralist reality that Presidents face. Indeed, some, such as Professor Calabresi and Lee Liberman, seem to deny that "presidentialism" and "political pluralism" are even genuine alternatives. They suggest that Presidents invariably operate within such politically tangled environments that, in a significant sense, giving the President a constitutionally guaranteed "last say" over all bureaucratic policy would not affect outcomes very much. ${ }^{153}$ Competing forces are always so strong that a presidentialist bureaucracy would be, more or less, the pluralist bureaucracy we now have anyway.

That speculation, however, seems ironic, especially coming from Ms. Liberman, who served President Bush so ably as an Associate Counsel to the President. If we credit the hypothesis of insignificance, then the extraordinary efforts of both the Reagan and Bush Administrations to establish their legal claims to presidential policy control over the entire bureaucracy would appear utterly irrational. Not

1966) (vacating adjudicatory order on grounds of excessive congressional intervention).

152. I use the word "pluralism" to refer only to the multiplicity of legitimate and effective political forces that may be brought to bear on an agency, not to embrace any particular normative theory of politics, for example, "pluralism," as distinguished from "civic republicanism." See William N. Eskridge, Jr. \& Philip P. Frickey, Cases and Materials on Legislation: Statutes and the Creation of Public Policy 46-64 (1988).

153. Steven Calabresi and Lee Liberman, Esq., Remarks at symposium "Law of the Presidency: Separation of Powers," University of Arkansas School of Law at Fayetteville (Apr. 14-15, 1994). 
only would they have risked (and incurred) significant judicial rebukes and congressional antagonism, but they would have done so for no genuine reason. That seems implausible. It seems more likely, given how strongly Presidents have urged the presidentialist model, that a presidentialist bureaucracy and a politically pluralist bureaucracy would behave in significantly different ways.

One dimension of that difference might well be accountability. Unfortunately, it is a striking feature of most of the "unitary executive" literature that it gives little sustained attention to what "accountability" means. ${ }^{154}$ The connection between presidential control of administration and accountability is offered as self-evident. Of course, if one simply defines "accountability" as the vesting of ultimate decisional authority in a person who is elected, not appointed, it is, indeed, self-evident that the President is elected, and bureaucrats are not. Voters have one-albeit no more than one-opportunity to vote "No" on extending a President's White House stay. Bureaucrats do not run for office.

But no adequate analysis can rest entirely on that observation. The point of accountability, by definition, must surely be the actual operational capacity of any decision maker to be held to account. It is not at all self-evident that the President is more accountable in this sense than other public officials. Moreover, once we address accountability in operationally realistic, non-tautological terms of actual responsiveness, it is clearly imperative to ask: Exactly who is empowered to hold decision makers to account, when, and for what? The answers to these questions are far from obvious. To pursue them, it is important to consider a variety of hypotheses as to the kinds of accountability that one can imagine achieving, at least in part, by attending to the allocation of policy making control within the executive.

154. Professor Calabresi's contribution to this symposium is a notable exception to this generalization, given his systematic attempt to link the unitary executive with a clearly expressed model of responsiveness to a national electoral constituency. Calabresi, supra note 1 , at 58-70. 


\section{Accountability to Public Opinion}

One obvious possibility would be to pursue accountability as embodied in a policy maker's fidelity to the current policy preferences of the electorate at large. Can we predict that a strong unitary executive would be more likely to be accountable in this sense than an executive exhibiting fairly diffuse policy making power?

The answer seems obviously negative. There is no evidence that the President, at any given moment, embodies that set of policy predilections across a wide set of issues that is held by a contemporaneous majority-or, more accurately, by contemporaneous majorities of Americans. Indeed, one of the most remarkable features of the Reagan Presidency was the dissonance between his strong electoral mandates and the public's apparent rejection of his policy positions on a variety of highly significant issues. ${ }^{155}$ This emphatically is true with respect to environmental regulation. Throughout the RB era, consistent and overwhelming majorities of Americans subscribed to the view that the quantity of U.S. environmental regulation was appropriate or too low. ${ }^{156}$ The position implemented by the Council on Competitiveness - that we have too much environmental regulation-has never approached becoming a majority view in the last 20 years.

There is one most obvious reason why the President would mirror public opinion polls quite imperfectly-the

155. For example, the Reagan Administration never secured anything approaching majority support for its policy of aiding the Contras. BenJamin I. PAGE \& RoBert Y. Shapiro, The Rational Public: Fifty Years of Trends in Americans' Policy Preferences 274-80, 372 (1992); Shane, supra note 4, at 395 n.146. Moreover, despite their ardent anti-abortion stances, neither President Reagan, nor President Bush, ever persuaded a majority of Americans that abortion should remain unavailable in most cirumstances. The percentage of people who say they support Roe v. Wade actually rose in the late 1980 s, and after a temporary dip in early 1992 , continued to rise to a rate of $65 \%$ support in January, 1993. Joan Biskupic, Argument Without End, WASH. Post NAT'L WKLY. Edition, Feb. 1-7, 1993, at 10, 11.

156. A search of the WESTLAW, Poll Database, indicates that the Roper Center has regularly surveyed public opinion on the question whether environmental protection laws and regulations have gone too far, or not far enough, or have struck about the right balance. The following chart tabulates percentage results for these surveys: 
President is a single person. ${ }^{157}$ Assuming it is even possible to identify, at a given moment, the full array of value judgments that various majorities of Americans hold across a comprehensive range of important public policy issues, it is doubtful that the resulting attitudinal profile would be sufficiently coherent to impute it to any single personality. A President whose every view tracked the majority in the lat-

\begin{tabular}{lcccc}
\hline Year of Survey & Gone too far & Not far enough & Right balance & Not sure \\
\hline 1980 & 25 & 33 & 33 & 10 \\
1981 & 21 & 31 & 38 & 10 \\
1982 & 16 & 37 & 38 & 9 \\
1983 & 14 & 48 & 30 & 9 \\
1985 & 16 & 45 & 29 & 19 \\
$7 / 1990$ & 4 & 69 & 17 & 10 \\
$12 / 1990$ & 12 & 63 & 19 & 6 \\
1992 & 10 & 63 & 17 & 10 \\
\hline
\end{tabular}

Roper Reports, Roper Center for Public Opinion Research, Oct. 1980, Oct. 1981, Oct. 1982, Oct. 1983, Nov. 1983, July 1990, Dec. 1990, June 1992, available in DIALOG, Public Opinion Online (POLL) database.

157. Public choice theorists typically invoke Arrow's Theorem to "prove" that a legislature governed by majority rule cannot reach an optimal "resolution among three or more mutually exclusive alternatives that are voted on pairwise." EsKRIDGE \& FRICKEY, supra note 152, at 50. Given presidential candidates who represent dozens of alternative policy positions on matters of interest to voters, it is surely even less plausible that an electoral victory for a single candidate represents an optimal resolution of voter disagreements on all of those issues. On the "practical impossibility in our political system of ascertaining mandates" through presidential elections, see Nelson W. Polsby \& Aaron B. Wildavsky, Presidential Elections: Strategies of American Electoral Politics 268-74 (6th ed. 1984).

Although the thoughtfulness of his overall discussion is surely impressive, Professor Calabresi tries to dodge this argument with what seems to me a conspicuous and unresponsive example of pleading in the alternative. First, he urges, citizens should not worry about presidential nonresponsiveness because Presidents adjust their positions over time. Calabresi, supra note 1, at 68-69. But, even if they don't, citizens still should not worry because Presidents are out of office in four or eight years, in any event, and the business cycle likely ensures that neither "the cultural right or the cultural left will dominate the presidency over time." Id. at 69.

These arguments are unpersuasive because neither meets the point that a President, while in office, has significant latitude to be nonresponsive to popular majorities. This is so, not as conjecture, but as fact. Presidents Reagan and Bush never had majority support for their views on the Contras or on environmental policy; they never shifted their views to accommodate the majority. Moreover, in Reagan's case, presidential elections did not prove a significant disciplinary force. In Bush's case, they perhaps did, but only after four years in which the White House was consistently out of touch with the popular majority's views of environmental policy-and without effective recourse. Professor Calabresi's assurance that "bundling is a problem, at most, for short periods of time," $i d$. at 69 , is true only if one counts four years as "short," which no politician does. 
est relevant opinion poll would presumably be so conspicuously lacking in any internal compass as to call into question at least the President's capacity for leadership, not to mention his mental health.

Fans of the unitary Presidency are fond of pointing to the framers' explicit decision neither to vest executive power in a plural executive, nor to create an executive council to guide the President. ${ }^{158}$ As much as anything, however, that decision reflects an implicit rejection of political representativeness as an intended feature of the chief executive. Had representativeness been the goal, surely a multiple presidency would have been preferable. ${ }^{159}$

Moreover, the President's incentives to follow the polls in any close way are not as strong as is often assumed. After all, despite common academic references to a presidential candidate's unique "national constituency," any candidate is subject to election only twice. Two considerations seem to outweigh all others in recent choices of Presidents-public satisfaction (or the lack of it) with economic performance under the most recent incumbent, and a general sense of an incumbent President's personal performance. ${ }^{160}$ Thus, during both an initial campaign and another for reelection, a presidential candidate knows that his detailed stances on matters of policy are not likely to make decisive differences in his political fortunes. And, of course, following a successful reelection campaign, there is

158. Professor Calabresi, for example, celebrates the framers' decision to sweep the "plural executive forms into the ash bin of history." Calabresi, supra note 1 , at 25 .

159. In a wonderfully original and provocative analysis, John Rohr has suggested that the Senate was imbued with significant executive powers-and, indeed, conceptualized by the framers as possessing a partly executive character-to compensate, in part, for the nonrepresentative character of the Presidency. JoHN A. ROHR, To Run a Constitution: The Legitimacy of the Administrative State 28-39 (1986).

160. On elections through 1984, see Stephen J. Wayne, The Road to the White House: The Politics of Presidential Elections 252-69 (3d ed. 1988). On Election Day, 1992, $42 \%$ of the voters responding to a poll by a consortium of television news organizations identified "the economy" as the most important issue in casting their votes. The closest runners-up were the "federal deficit" and "health care"-both closely correlated to economic worries-with 21 and $20 \%$, respectively. The American Enterprise, Jan.-Feb. 1993, at 93. 
no further prospect of confronting the electorate to discipline a President's policy judgments.

If bureaucratic accountability to elected politicians is to be used as a structural mechanism aimed at achieving direct responsiveness to public opinion, it would probably make more sense to intensify the influence that Congressespecially the House-has over the agencies. Members of Congress are eligible for reelection indefinitely; a common observation of the House is that its members are in a constant election campaign. One would thus expect the policy output of Congress to track public opinion more conscientiously than would the President's day-to-day agenda, as did, indeed, the pro-environmentalist Congresses of the 1980s. ${ }^{161}$

There is, however, an obvious complication here. To the extent a President relaxes his policy oversight of an agency, one expects to find a shift in policy influence not to Congress in general, but rather to the committees that oversee a particular agency. ${ }^{162}$ The influence OIRA loses is presumably the influence that committee chairs gain. Thus, even if the policy predilections of Congress track public opinion closely, a particular committee might not be an effective microcosm of Congress.

Interestingly, an important recent study may assuage that concern. Professors Kiewiet and McCubbins argue that the majority parties in Congress have effectively delegated power through the committee system in a way that yields "a strong and systematic influence" by the parties over Congress as a whole. ${ }^{163}$ If committees actually replicate the dominant policy views of Congress as a whole, then

161. Henry Kenski \& Margeret Corgan Kenski, Congress Against the President: The Struggle Over the Environment, Environmental Policy in the 1980s: ReaGan's New Agenda 97-120 (Norman J. Vig \& Michael E. Kraft eds., 1984).

162. On this basis, Professors Bruff and Gellhorn cautioned early against the use of the legislative veto as a device for improving "congressional" oversight of the executive branch. Harold H. Bruff \& Ernest Gellhorn, Congressional Control of Administrative Regulation: A Study of Legislative Vetoes, 90 HARv. L. REv. 1369 (1990).

163. D. Roderick Kiewiet \& Mathew D. McCubbins, The Logic of Délegation: Congressional Parties and the Appropriations Process 232 (1991). 
accountability to committees might be a decent proxy for accountability to dominant public opinion. ${ }^{164}$

It is important to remember that elected officials' pressure upon policy making bureaucrats is likely to be most salient when two conditions prevail. First, as is common, the relevant administrators must be implementing a statute that affords them sufficient policy making discretion within the four corners of the statute to make pressuring the agency worthwhile. Were any statute to provide a truly wooden administrative recipe, the institutional pressure simply to conform to the law would likely overwhelm political demands to depart from it. Second, pressure from political officials will be most important as an independent mechanism for achieving accountability to current public sentiment when significant time has elapsed between the enactment of a statute and its implementation. When an agency's task is to implement a statute enacted quite recently, then the statutory enactment itself should reflect dominant national sentiment. Any pressure to conform to such sentiment-as opposed to pressure simply to enforce the law-would seem superfluous. In other words, conformity to the value structure animating a very recent enactment will suffice to produce policy outcomes consistent with the views of a contemporary majority.

Indeed, when an agency is administering a recently enacted law, the independent political pressures of a presidentialist hierarchy can dangerously derail an agency's fidelity to the political intentions underlying the act. Assuming that the statute leaves implementing administrators significant room for discretionary judgment, a President vested with strong control powers could pressure the agency to adopt a mode of implementation more reflective of his unilateral preferences than of the compromise among competing positions that had to be struck in order to get the law enacted. ${ }^{165}$ The President may abandon his bargains because Congress can discipline the President only by legislat-

164. See K. Krehbiel, Information and Legislative Organization (1991).

165. For a game-theory explication of this point, see Matthew D. McCubbins et al., Structure and Process, Politics and Policy: Administrative Arrangements and the Political Control of Agencies, 75 VA. L. REv. 431, 435-40 (1989). 
ing over the President's veto-a formidable task under almost all political circumstances. ${ }^{166}$

It is of considerable interest that several political scientists have recently suggested that our traditional, procedurally oriented structure of administrative law, which assigns significant decisional independence to individual agencies, may be well designed precisely to secure administrative action consistent with the transactional intent embodied in whatever statute authorizes that action. ${ }^{167}$ The argument is complex, controversial, and far from conclusive. ${ }^{168}$ It raises serious issues, however, for anyone claiming that fidelity to public opinion requires tight presidential oversight of administrative decision making.

\section{Accountability to Affected Interests}

For a different reason, it might be that checking bureaucratic behavior through the control of any political official will be unsuccessful in enabling current popular majorities to secure administrative decisions consistent with their views. Politicians may simply be less responsive to electoral majorities per se than to dominant sentiments among those persons whose stake in a government decision are great enough to promote their organization into effective pressure groups. ${ }^{169}$ This is not invariably a problem. Responsiveness to those most affected by bureaucratic decision making might even be a preferable accountability goal, especially if we were confident that all those who stand to

166. Charles Black, Some Thoughts on the Veto, 40 Law \& Contemp. Probs. 87, 93-98 (1976). Despite Democratic majorities in both Houses of Congress and often unimpressive approval ratings, President Bush successfully vetoed 46 bills during his term of office. He lost on only one override, the 1992 cable television reregulation bill. The Senate voted to override two other vetoes, which the House sustained; the House voted to override five other vetoes, which the Senate sustained. President Bush's Vetoes, 50 Cong. Q. WKLY. ReP. 3925 (1992).

A recent and extremely thoughtful analysis of the President's capacity to use the veto to entrench his own view of the law is Abner S. Greene, Checks and Balances in an Era of Presidential Lawmaking, 61 U. CHI. L. Rev. 123 (1994).

167. McCubbins et al., supra note 165; Mathew D. McCubbins et al., Administrative Procedures as Instruments of Political Control, 3 J.L. EcoN. \& ORG. 243 (1987).

168. See, e.g., Glen O. Robinson, Commentary on Administrative Arrangements and the Political Control of Agencies: Political Uses of Structure and Process, 75 VA. L. REV. 483 (1989).

169. EsKridge \& Frickey, supra note 152 , at $48-50$. 
gain or lose substantially through a particular decision were represented with equal effectiveness.

Under this model, however, a tight concentration of power over bureaucratic decision making would seem to impede, rather than advance, the cause of accountability. The interests affected by truly significant regulatory decisions are likely too numerous and diverse. They need realistic opportunities to secure the effective representation of their views, and meaningful mechanisms for a policy dialogue that seriously takes account of all that is at stake in an administrative decision. Neither of these accountability preconditions is well served by rigid hierarchical decision making. It is precisely the large size and relative openness of Congress that makes it realistic to hope that all interests relevant to a policy decision will find some effective legislative representation and voice. If ultimate policy making power were lodged in a single individual, such an arrangement necessarily would increase the chances that one interest or set of interests will have disproportionate access and influence. ${ }^{170}$

It is troubling yet again from an "affected interests" perspective on accountability that the presidentialist model would so easily permit a President to disturb the equilibrium that such interests have reached in striking a bargain over authorizing legislation. It is only when Congress, the President, and public interest groups enjoy rough parity in their capacity to shape agency behavior that the political environment is likely to replicate the conditions that produced whatever legislation the agency is implementing. ${ }^{171}$ In other words, vesting policy authority in an administrator who enjoys independent discretion, but who also faces politically pluralist decision making conditions, is most likely

170. As one recent commentator has said: "[A]ny suggestion that resisting specialized appeals is best done by concentrating power in the President is clearly counterfactual, as the Framers themselves recognized." Jonathan R. Macey, Comment: Confrontation or Cooperation for Mutual Gain? 57 LAw \& CONTEMP. ProBs. 45, 50 (1994).

171. See generally McCubbins et al., supra note 165; McCubbins et al., supra note 167 : 
to produce policy outcomes consistent with the array of political forces embodied in a statute. ${ }^{172}$

By contrast, neither Congress, nor members of the public most affected by regulatory decisions, seriously can hope to discipline the abandonment by a "unilateralist" President of an earlier compromise once a piece of authorizing legislation is enacted. A President's faithlessness rarely is sufficient to animate a two-thirds legislative majority against him, and his abandonment of particular interests in a particular episode is not likely to be so important to his reelection prospects-if he has any-to deter a President determined to go his own way.

\section{Accountability to the "Public Interest"}

There is, of course, yet another political tradition within which to construct an ideal of accountability. We could hope for a system most likely to check the bureaucracy not when it veers from majority opinion, or even from the opinions dominant among the most affected parties, but rather when it departs from a more dispassionately determined "public interest" that may or may not coincide with polling results. Such, of course, was James Madison's organizational ideal. He argued for a constitutional design intended above all to constrain the influence of "faction," which he brilliantly defined as:

a number of citizens, whether amounting to a majority or minority of the whole, who are united or actuated by some common impulse of passion, or of interest, adverse to the rights of other citizens, or to the permanent and aggregate interests of the community. ${ }^{173}$

Professor Cass Sunstein is among the most energetic of our colleagues in centering public law scholarship on the Madisonian ideal. ${ }^{174}$ His work properly gives prominence

172. For an argument that public interest groups assist in this dynamic, see Daniel A. Farber, Politics and Procedure in Environmental Law, 8 J.L. Econ. \& ORG. 59 (1992).

173. The Federalist No. 10, at 78 (James Madison)(Clinton Rossiter. ed., 1961)(emphasis added).

174. See, e.g., Cass R. Sunstein, Beyond the Republican Revival, 97 YALE! L.J. 1539 (1988); Cass R. Sunstein, Interest Groups in American Public Law, 38. StaN. L. Rev. 29 (1985). 
to open, vigorous government dialogue as perhaps the chief constitutional instrument for elevating the public interest over faction. ${ }^{175}$ But, if he is right on these counts-and I think he is - then he undermines the Lessig-Sunstein case for the plenary presidential removability of administrators. Administrative decision making in the public interest requires an extension to the executive branch of a policy dialogue that is vigorous, thorough, and reasoned. As Professor Luneberg has argued, the plenary removability of administrators is far more likely to inhibit, rather than advance robust intrabranch policy debate. ${ }^{176}$ To achieve intrabranch dialogue, it is thus important not to tighten the reins on subordinates, but to provide incentives for subordinates to speak freely and for the President actually to listen to diverse voices despite the predictable dominance of his own. ${ }^{177}$

Besides the virtues of dialogue, those who believe in the ascertainability of a "public interest" beyond opinion polls are likely also to trumpet the virtues of dispassionate expertise as a central feature of administrative decision making. Expertise provides a foundational rationale for the entire phenomenon of specialized agencies under different administrators. Each agency, because of its discrete jurisdiction and sustained immersion in particular categories of problems, is expected to develop a base of knowledge and methodological sophistication intended to protect against decision making based solely on passion or "interest."

Because the ideal of expertise argues so obviously for diffusing policy making authority to specialized agencies, contemporary advocates of presidential control typically assert that "we" have now outgrown any naive New Deal faith in neutral expertise as a governing force in decision making. Lessig and Sunstein argue that "once one sees the nature of administration as fundamentally political ..., the

175. Cass R. Sunstein, Constitutionalism After the New Deal, 101 Harv. L. Rev. 421, 430-37 (1987).

$\checkmark 176$ : William V. Luneberg, Civic Republicanism, the First Amendment, and Executive Branch Policymaking, 43 ADMIN. L. Rev. 367, 403-04 (1991); see also Michael Fitts, The Vices of Virtue: A Political Party Perspective on Civic Virtue Reforms of the Legislative Process, 136 U. PA. L. REv. 1567 (1988).

177. Luneberg, supra note 176, at 403-04. 
whole notion of independent political bodies becomes highly problematic." 178 But, there is a real world of difference between "fundamentally political" and "exclusively political." It is far from obvious that only the naive among us can aspire to policy making that, while deeply political, also has a serious, well-trained, technically sophisticated and disciplined eye on a reality apart from politics. After all, even a politically anti-abortion Surgeon General was able to determine during the most socially conservative Presidency of this century that extensive study had failed to yield credible evidence that abortion produces enduring psychological trauma in once-pregnant women. ${ }^{179}$ Such an episode reveals a bureaucratic capacity to attend to fact in a way that exemplifies an important bureaucratic ideal. ${ }^{180}$ If the country wants decision making attentive to "the permanent and aggregate interests of the community," thoughtfully determined, then decision making structures should maximize opportunities for transcending partisanship and ideology. Tightly hierarchical structures do not.

178. Lessig \& Sunstein, supra note 1 , at 101.

179. Martin Tolchin, Koop's Stand on Abortion's Effect Surprises Friends and Foes Alike, N.Y. TiMES, Jan. 11, 1989, at A20, available in LEXIS, Nexis Library, Arcnews File.

180. A case I frequently discuss with administrative law classes in this respect is Association of Nat'l Advertisers v. Federal Trade Comm'n, 627 F.2d 1151, cert. denied, 447 U.S. 921 (1980)[hereinafter $A N A$ ]. In $A N A$, the D.C. Circuit rebuffed a trade association's attempt to disqualify FTC Chairman Michael Pertschuk from participating in a rulemaking that proposed restrictions on television advertising directed to children, including ads for "sugared products." Pertschuk had, to put it mildly, expressed a proregulatory disposition on the issue, calling for a "fundamental assault on television advertising directed toward young children." Id. at 1191 (MacKinnon, J., dissenting in part and concurring in part). The Court nonetheless drew a categorical distinction between adjudicatory policymaking aimed at the neutral discernment of specific facts and the more politicized, value-centered function of general policy making. It held that an administrator could be disqualified from participating in a policy making proceeding only upon "a clear and convincing showing that [the decision maker] has an unalterably closed mind on matters critical to" the process. Id. at 1154 .

This may be fine as a judicial standard, but the implication that personal opinion may appropriately submerge all other considerations in even so obviously political a rulemaking is highly troubling. It would surely have been objectionable if the FTC regulated advertising to children without any dispassionate inquiry as to the nature of children's understanding of advertising, the actual harms from an overconsumption of sugar and their prevalence, the likely effectiveness of alternative regulatory approaches in changing behavior, and so on. 


\section{Transparency in Decision Making}

Among the papers I've misplaced over the years, one of my favorites was a cartoon of two figures speaking against the backdrop of the Capitol dome. One says to the other: "I love the separation of powers. No matter what goes wrong, there's always somebody else to blame." Such a jibe might suggest that, whatever the answer to my earlier query - "Who is empowered to hold decision makers to account, when, and for what?"-presidential bureaucratic control would be helpful because it would help answer a briefer question: "Who's to blame?" In other words, it is a problem that anyone authorized to hold decision makers to account in a politically pluralist system is nonetheless often unable to identify the relevant decision makers. The framers expressly noted this problem in deciding to vest executive power in a single, rather than in a plural President:

$[\mathrm{O}]$ ne of the weightiest objections to a plurality in the executive ... is that it tends to conceal faults and destroy responsibility. ... [T] he multiplication of the executive adds to the difficulty of detection .... ${ }^{181}$

From this point of view, the virtue of presidentialism would be its contribution to decisional transparency.

Despite the crispness of this proposition, it is in one sense operationally unlikely and, in another, operationally insignificant. It is operationally unlikely because, to a great extent, even the vesting of ultimate decisional authority in the President will not undo the ubiquitous possibilities that a complex bureaucracy affords to disavow responsibility for unpopular choices and to claim the chief credit for successes. Presumably, the President already exercises numerous authorities and functions of which the public is unaware, and which the White House does not highlight. As related above, a major goal animating the Council on Competitiveness was to keep the President personally uninvolved in contentious regulatory decision making. The likely intent was to give the President the prerogative-at least in friendly audiences-to embrace the Council whole-

181. The Federalist No. 70, at 427-28 (Alexander Hamilton)(Clinton Rossiter ed., 1961). 
heartedly for advancing his values, while keeping intactpresumably in other audiences - the plausibility of denying direct responsibility for any particular thing the Council had done.

Indeed, for those who embrace categorical separationism as a constitutional reading, this problem is exacerbated by their faith in executive privilege. Under United States $v$. Nixon, the President's entitlement to keep his communications at least presumptively confidential is rooted in the notion that the executive must be able effectively to discharge inherent executive power. ${ }^{182}$ It would have to follow logically that ascribing to the President an extravagant range of inherent power would correspondingly expand his capacity to keep his secrets. That privilege would make it harder, not easier, to determine "whom to blame." And, if the point were not obvious from logical analysis alone, it would be proved by Congress's conspicuously greater success in overseeing domestic policy making - where executive privilege claims are most dubious - than foreign and military policy making - where executive privilege claims traditionally are most credible. ${ }^{183}$

The reason for the insignificance of the transparency argument is that, even without plenary power to secondguess all bureaucratic policy makers, the President may well be held generally and properly accountable for overall bureaucratic performance in any event. That is because voters know the President has appointed all key policy makers and the most important managers of executive affairs. The President's value structure is likely to dominate the bureaucracy even if he is not formally able to command all important policy decisions. Professor Abner Greene has recently catalogued a series of reasons why this is so: OMB reviews virtually all agency budgets; the Attorney General controls most agency litigation; the President's support may be critical to an agency in its negotiations with Congress. ${ }^{184}$ For these reasons, Presidents do not inevitably have less influ-

182. 418 U.S. $683,705-06$ (1974).

183. Peter M. Shane, Negotiating for Knowledge: Administrative Responses to Congressional Demands for Information, 44 ADmin. L. Rev. 197, 224 (1992).

184. Greene, supra note 166 , at 178-79. 
ence over "independent" agencies than they do over "purely executive" establishments. ${ }^{185}$

There is, in addition, another reason for thinking that any link between presidential policy control and decisional transparency is a red herring. As noted earlier, the alternative to presidentialism is political pluralism, not genuine agency independence. Presidents always have influence, but, in a pluralist world, they have to compete on a more level playing field with Congress in keeping the heat on agency administrators. Conversely, if the President were to enjoy more and more complete control over the content of domestic policy, then the weaker the identifiable link would become between legislator effectiveness and government performance. There seems to be a kind of "conservation of accountability" law at work here, under which decisional transparency on one end of Pennsylvania Avenue becomes plausible deniability on the other. The more public leverage over the President becomes an effective lever over bureaucratic output, the less effective congressional elections would seem to be in achieving policy accountability.

\section{B. Accountability and Regulatory Oversight}

Once we attend to the genuine intricacies of what accountability means, any easy equation disappears between the ideal of accountability and the practice of tight White House control over regulatory policy making. At the very least, that equation becomes far too controversial to sustain the argument that accountability concerns mandate a constitutional reading that necessitates complete presidential control of agencies. ${ }^{186}$

We have identified at least three political measures against which to hold government decision making accountable: the majority views among voters, the dominant sentiments among affected parties, and a dispassionately determined public interest. Moreover, our governmental

185. Neal Devins, Political Will and the Unitary Executive: What Makes an Independent Agency Independent?, 15 CARDOzO L. Rev. 273 (1993).

186. I have made this point earlier. Peter M. Shane, Independent Policymaking and Presidential Power: A Constitutional Analysis, 57 Geo. WASH. L. Rev. 596, 623 (1989). 
system contains a variety of instruments that could plausibly be used to secure some correspondence between bureaucratic decision making and any of these measures. These include presidential elections, congressional elections, presidential oversight, congressional hearings, appointments and removals, confirmation proceedings, administrative procedures, judicial review, and grass roots public pressure.

But what accountability requires, under all the theories mentioned, is a set of political conditions that is fairly complex. Perhaps the most important is widespread access to information about the nature of the decisions at issue. A second is policy dialogue, and a third, a multiplicity of opportunities for dialogue to be well-informed and salient to actual decision making. A fourth is flexibility in the value structure of bureaucratic decision making. The more procrustean the decision making environment, the less accountable it is to anyone but to the ultimate decision maker.

By each of these measures, the model of regulatory oversight depicted in Executive Order No. 12,866 looks far more attractive than the model actually operationalized by President Bush's Council on Competitiveness. The Order envisions considerable openness in the regulatory process, and relatively broad public access to relevant intrabranch and outside communications. The Council, in sharp contrast, strove to keep its policy input confidential. ${ }^{187}$ It is perhaps more than symptomatic that the average lawyer would find it difficult to locate the obscure memoranda that chartered the Council, as compared to the codified and readily accessible description of regulatory process the executive order provides.

Second, the Clinton executive order is far more tolerant of diffuse policy making influence. OIRA's capacity to strong-arm agencies is reduced both in the formal description of its powers and through its susceptibility to deadlines. As a consequence, more relevant actors have more plausi-

187. See supra text accompanying notes 58-64. 
ble opportunities to contribute to the policy making process in an influential way.

Finally, the order is more eclectic than the Counciland than President Reagan's earlier executive order-in its articulation of an appropriate value structure to guide regulatory policy making. The problem confronting the drafter of any such directive, whether an executive order on regulation or the increasingly ubiquitous "strategic plan" for higher education, is to be concrete enough to be meaningful, while remaining general enough to be sound. It seems a fair prediction that policy making consistent with the tenor of the Clinton executive order will weigh certain policy priorities over others; its philosophy, however, does not elevate any one single value (such as efficiency) to so dominant a position as to pose an immediate and ineluctable conflict with the competing goals animating a wide range of statutes.

Of course, this analysis suffers the distortion of comparing a paper model of policy making with flesh-and-blood experience. My observation, however, is that the actuality of the Council on Competitiveness only substantiates the analytical problems I earlier identified in linking the ideal of accountability to tightly controlled, highly centralized oversight. The Council was not effective in increasing the correspondence between agency outcomes and popular opinion. Its insistence on environmental deregulation consistently defied majority popular sentiment. ${ }^{188}$ Nor does the Council seem to have improved the Government's responsiveness to the full range of interests affected by regulation. Pious denials notwithstanding, the alignment of the Council's agenda with that of organized business strongly suggests that some interests were treated as invariably weightier than others. ${ }^{189}$ This last fact also strongly undermines any suggestion that the Council made a positive contribution to aligning policy outcomes more consistently with a dispassionately determined public interest. The Council seemed not to suppress special interest factionalism, but to

188. See supra note 156.

189. Cf. Victor, supra note 24 . 
cater to it, submerging, rather than elevating, policy dialogue. Its policy directives sometimes tended to ignore contrary expert judgment in favor of an overwhelming ideological commitment to deregulation for its own sake. Such a result is unsurprising given that the Council's chair, Vice-President Quayle, described himself as a "zealot" for deregulation. ${ }^{190}$ Zealotry and the public interest would seem unlikely companions.

\section{CONCLUSION}

Once we plumb the complexities of both defining and operationalizing accountability, a strong case appears that tight unitary control of the executive is a problematic model. Virtually every plausible normative version of accountability seems to depend quite strongly on the availability of multiple pressure points within the bureaucracy, a diffusion of policy making influence, public dialogue, and a general fluidity in the value structure that guides the bureaucracy's decision making. In all these respects, the system described in ideal terms by Executive Order No. 12,866 would clearly be preferable to the actual operation of the Council on Competiveness.

For constitutional theorists, these conclusions have two implications. If originalist interpretation does not sustain an argument for inherent presidential power to control all bureaucratic decision making in domestic affairs, then the case for categorical separationism as a constitutional command must fail altogether. A realistic account of the actual mechanics of government accountability does not categorically link the "unitary presidency" with the accountability ideal. Thus, contrary to the Lessig-Sunstein thesis, functionalist reasoning does not provide the argument for presidential control that originalism fails to support. The reverse is more likely to be true.

Second, even if the originalist argument for presidential control is stronger than I believe, a President with constitutional authority to engage in a tightly hierarchical mode of bureaucratic management might serve the country

190. Woodward \& Broder, supra note 21 , at A1. 
best through presidential forbearance. As Professor Shapiro has argued recently in a thoughtful article, the President would likely help create the greatest public welfare gains, not through micromanagement of individual regulations, but by fostering careful planning of the bureaucracy's regulatory agenda and promoting interagency coordination. ${ }^{191}$ Again, the Council on Competitiveness provides the wrong model to follow.

It is finally worth emphasizing, however, that the relationship between general institutional structures and actual political behavior is likely to be a loose one. The "purely executive" EPA under a Reilly or Ruckelshaus proved notably less compliant than the "independent" Reagen-era FTC, FCC, and NLRB. Recognizing that the scope of presidential influence over the bureaucracy is itself a legitimate subject of political contestation would allow that scope to vary-perhaps as functionally appropriate to the bureaucratic tasks at hand. ${ }^{192}$

For all these reasons, constitutional theorists who prize bureaucratic accountability should abhor any reading of the Constitution that mandates a single structural route towards its realization. The Constitution's contribution to accountability depends primarily upon its structure of checks and balances. Keeping agencies attentive to multiple voices

191. Sidney A. Shapiro, Political Oversight and the Deterioration of Regulatory Policy, 46 Admin. L. Rev. 1 (1994).

192. Assistant Attorney General and Duke law professor Walter Dellinger, whose presidential lawyering is informed by an exceptional breadth of historical and legal background, has implied that challenges to the notion of constitutionally mandated plenary presidential control of the bureaucracy is somehow "anti-politics." He specifically bemoans a policy making atmosphere in which presidential interest in the substance of policy making is deemed suspect, if not corrupt. He regrets that the President is often open to criticism simply for injecting into the processes of bureaucratic decision making the very values that got the President elected in the first place. Walter E. Dellinger III, Remarks at symposium "Law of the Presidency: Separation of Powers," University of Arkansas School of Law at Fayetteville (Apr. 14-15, 1994).

I- share his worry and concur in his regret, but not with his characterization of arguments of the type I have made. My argument fully embraces the President's political role. And my vision of the Constitution is profoundly pro-politics because (1) it renders the scope of presidential influence over the bureaucracy a legitimate subject of political struggle, and (2) assures that bureaucratic agencies will be politically buffeted from many sides, not only by the President. 
is likely to maximize the dialogue, openness, and responsiveness that define accountability in its most important sense. 